\title{
Air Pollution, Stock Return, and Volatility: Evidence from Korean Stock Markets
}

\author{
Taekyung Kim, Ph.D. Candidate, Chung-Ang University \\ Shiyong Yoo ${ }^{*}$, Professor, Chung-Ang University
}

\begin{abstract}
$<$ Abstract $>$
This study analyzes the direct and indirect effects of air pollution on the return and volatility of the KOSPI index through the trading ratio by investor type. The main results are as follows. First, air pollutants have a direct effect on volatility; coarse particulate matter $\left(\mathrm{PM}_{10}\right)$ and fine particulate matter $\left(\mathrm{PM}_{2.5}\right)$ have a negative effect on volatility. Second, air pollutants have a significant effect on the trading ratio by investor type; as the concentration of fine particulate matter $\left(\mathrm{PM}_{2.5}\right)$ increases, the trading ratio of institutionals and those of foreigners decrease. Third, the effect of cumulative exposure of air pollutants on stock return and volatility is greater than that of daily exposure. Although there is no effect on daily exposure to air pollution, stock return decreases during cumulative exposure to fine particulate matter $\left(\mathrm{PM}_{2.5}\right)$, nitrogen dioxide $\left(\mathrm{NO}_{2}\right)$, and carbon monoxide $(\mathrm{CO})$. The volatility changes significantly with cumulative exposure compared to daily exposure to coarse particulate matter $\left(\mathrm{PM}_{10}\right)$, fine particulate matter $\left(\mathrm{PM}_{2.5}\right)$, ozone $\left(\mathrm{O}_{3}\right)$, nitrogen dioxide $\left(\mathrm{NO}_{2}\right)$ and sulfur dioxide $\left(\mathrm{SO}_{2}\right)$. Fourth, air pollutants have an indirect effect on stock return and volatility through trading ratio by institutional and foreign investors. In particular, the effect of air pollution through the foreign investors' trading ratio is a remarkable result revealed in this study.
\end{abstract}

Keywords: Air Pollution; Investor Mood; Return; Volatility; Trading Ratio by Trader Type

JEL Classification: G02

\footnotetext{
* Corresponding Author. Address: Chung-Ang University, 84 Heukseok-ro, Dongjak-gu, Seoul, Korea 06974; E-mail: sy61@cau.ac.kr; Tel: + 82-2-820-5578; Fax: + 82-2-817-4891.
}

Received: September 26, 2019; Revised: November 27, 2019 \& December 24, 2019 ; Accepted: January 28, 2020 


\title{
대기오염물질과 주가 수익률 및 변동성
}

\author{
김 태 경 (중앙대학교 박사과정) \\ 유 시 용 (중앙대학교 교수)*
}

\author{
<요 약>
}

본 연구는 투자자별 거래비중을 통해 대기오염 코스피지수의 수익률 및 변동성에 미치는 직접적인 영향과 간접적인 영향에 대하여 분석한 첫 연구라는 점에서 의의가 있다. 주요 결과는 다음과 같다. 첫째, 대기오염물질은 지수변동성에 직접적인 영향을 미쳤다. 미세먼지와 초미세먼지는 지수변동성과 음(-)의 영향을 미쳤다. 둘째, 대기오염물질과 투자자별 거래비중 간에는 유의한 관계가 발견되었다. 초미세먼지의 농도는 기관의 매수비중과 외국인의 매도비중에 음(-)의 관계를 나타냈다. 셋째, 대기오염물질의 장기간 노출과 투자자별 거래비중과 지수수익률 간의 분석 결과, 초미세먼지와 이산화질소와 일산화탄소에 장기간 노출되면 지수수익률은 감소하였다. 미세먼지 초미세먼지, 오존에 지속적으로 노출되면 지수변동성은 감소하고, 이산화질소와 아황산가스에 지속적으로 노출될수록 변동성은 증가하였으며, 노출기간이 길수록 변동성에 미치는 영향도 크게 나타났다. 넷째, 대기오염물질은 기관과 외국인의 거래비중을 통해 지수 수익률 및 변동성에 간접적 영향을 미쳤다. 특히, 외국인투자자의 거래비중을 통한 대기오염이 주가 변동성에 나타난 영향은 본 연구에서 밝혀진 주목할만한 결과이다.

핵심 단어 : 대기오염, 투자심리, 수익률, 변동성, 투자자별 거래비중

JEL 분류기호: G02

* 연락담당 저자. 주소: 서울특별시 동작구 흑석로 84 중앙대학교 06974; E-mail: sy61@cau.ac.kr; Tel: 02-820-5578; Fax: 02-817-4891. 


\section{1. 서론}

최근 들어 국내 대기의 질이 급격하게 악화됨에 따라 황사, 미세먼지 등 대기오염에 관한 관심이 높아지고 있으며 2003년 12월에 ‘수도권 대기환경 개선에 관한 특별법'이 시행되면서 그 관심은 더욱 커지고 있다. 공기에 떠다니는 먼지 가운데 직경이 $10 \mu \mathrm{m}$ 이하의 물질을 미세먼지라 하며 이는 자동차, 공장 등에서 발생하여 대기 중 장기간 떠다니며 천식과 같은 호흡기계 질병을 악화시키고 폐기능의 저하를 초래한다. 일부 학자들은 대기오염물질의 영향력이 건강 악화에 국한된 것이 아니라 심리에 부정적인 영향을 미쳐 우울증이나 범죄율 증가와 같은 결과를 보인다고 주장한다(Lu et al., 2018; Lim et al., 2012). 행동재무학 (behavioral finance)은 금융시장에서 발생하는 이상현상들을 심리학의 관점에서 분석하는 학문으로, 투자심리에 영향을 미치는 환경 요인에 대하여 관심을 갖는 학자들이 생겨나기 시작했다. 다수의 학자들은 날씨가 투자심리에 영향을 미쳐 주가수익률 및 변동성에 영향을 미치는지 연구하였으며(Saunder, 1993; Cao and Wei, 2005; Lee et al., 2002; Goetzmann and Zhu, 2005), 2000년대 들어 환경에 대한 관심이 높아지면서 대기오염과 주가수익률 및 변동성 간의 관계에 관한 연구도 이루어졌다. Levy and Yagil(2011)은 대기오염으로 인한 기분 변화가 미국의 주가 수익률에 부정적인 영향을 미친다고 보고한 바 있다. Zhang et al.(2017)은 연무 오염이 중국 베이징의 상장회사의 주가 수익률 및 변동성에 미치는 영향에 대하여 분석하였고 연무가 주가 수익률에는 음(-)의 영향을, 주가변동성에는 양(+)의 영향을 미친다는 점을 밝혔다.

한편, 금융시장의 투자자 유형은 크게 개인, 기관, 외국인투자자로 나뉠 수 있다. 2018년 12 월 말 기준으로 금융감독원에 등록된 외국인투자자는 46,700 명이며 기관투자자의 비중이 높다. ${ }^{1)}$ 외국인투자자의 유가증권시장 상장주식 보유금액은 480.6 조 원에 달하며 포트폴리오 투자비중이 높고 주요 국적은 영국, 미국, 싱가폴 등 23 개의 국가에 분포되어 있다. 다수의 선행연구에서 투자자 유형별 거래량이 주식시장의 가격 및 변동성에 미치는 영향을 분석한 바 있다(Yun and Lee, 2003; Yoo, 2014). Khil et al.(2009)은 투자자 유형별 거래비중이 비대칭 변동성에 미치는 영향을 분석하여 개인투자자의 비중이 높을수록 비대칭 변동성이 증가하고 기관투자자 및 외국인투자자의 비중이 높을수록 비대칭 변동성은 감소하는 결과를 보였다.

한국은 대기오염이 투자심리를 변화시켜 주가수익률이나 주가변동성에 어떠한 영향을 미치는지 분석하기 위한 이상적인 환경을 제공한다. 기관투자자의 비중이 높은 선진국의 주식시장과는 달리 한국의 주식시장은 개인투자자의 비율이 높다(Ryu et al., 2017; Shim et al., 2015). 대기오염은 투자심리의 변화를 통해 한국 주식시장의 수익률 및 변동성에 모두 영향을 미칠 것이며, 개인투자자가 의사결정시 기분에 쉽게 영향을 받는다는 것을

1) 금융감독원(www.fss.or.kr) 자료, "18. 12월 중 외국인투자자 증권매매동향,” 2019. 9. 19. 
고려하면(Lee et al., 2002) 개인투자자의 거래비중이 높을수록 대기오염물질이 주식시장에 미치는 영향력은 더 클 것이라는 가설을 세울 수 있다. 그리고 외국인투자자의 대부분은 한국에 위치해 있는 것이 아니기 때문에 현지 날씨는 외국인투자자의 의사결정에 영향을 미치지 않는다고 알려져 있다(Kang et al., 2010). 이를 대기오염에 적용하여 대기오염물질은 외국인투자자의 거래 비중과 무관할 것이라는 가설을 세울 수 있다.

본 논문에서는 2015년 1월 1일부터 2018년 12월 31일까지의 대기오염물질의 농도와 국내 주식시장의 일별 자료를 통해 한국의 대기오염이 주식시장의 수익률 및 변동성에 미치는 영향에 대하여 알아보고자 한다. 분석하고자 하는 대기오염물질로는 미세먼지, 초미세먼지, 오존, 이산화질소, 일산화탄소, 아황산가스 등이 있으며, 개인, 기관, 외국인 등 주식시장의 세 가지 투자자 유형에 따른 대기오염물질과 주가수익률 및 변동성 간의 관계에 대하여 연구한다. 비록 국내에서 일산화탄소, 아황산가스 등 일부 대기오염물질의 농도가 감소하고 있음에도 불구하고, 의학 분야의 연구들에 따르면(Kim et al., 2018; Jung et al., 2018), 이들의 농도는 알레르기비염이나 소아 호흡기세포융합바이러스 발병률과 유의한 상관관계를 나타낸 바 있다. 따라서 이들 물질을 포함한 6가지의 대기오염물질이 국내 주식시장에 미치는 영향에 대하여 분석하는 것도 타당하다고 판단되며, 분석 결과, 6 가지 대기오염물질 모두 국내 주식 시장의 수익률 및 변동성에 유의한 영향을 미치는 결과를 보였다. 즉, 모든 정보가 주가에 반영된다고 주장하는 효율적 시장가설에서 생각해 본다면 대기오염물질의 농도 역시 미미 하게나마 주가에 반영된다고 할 수 있다.

본 연구의 차별점은 첫째, 한국의 대기오염물질과 주가수익률 및 변동성 간의 관계에 대하여 분석한 최초의 연구로서 국내 대기오염이 투자자의 정서변화를 통해 주식시장에 미치는 영향에 대하여 설명하고 있다. Levy and Yagil(2011)는 미국의 대기오염이 주식시장에 미치는 영향을, Lepori(2009, 2016)는 이탈리아의 대기오염이 주식시장에 미치는 영향을, Li and Peng(2016)은 중국의 대기오염이 주식시장에 미치는 영향을 분석하였으며 모두 유의미한 음(-)의 영향이 있음을 밝힌 바 있다. 둘째, 기존 연구는 대기오염물질이 지수 수익률이나 변동성에 직접 미치는 영향에 대해서만 분석한 데 반해 본 연구는 투자자 유형별 거래비중을 통한 대기오염물질의 간접적인 영향에 대해서도 분석하였으며, 개인보다는 기관과 외국인의 거래비중을 통한 간접효과가 나타났으며 연구가설과는 반대되는 결과를 나타냈다. 셋째, 대기오염물질의 노출기간을 세분화해서 노출기간에 따른 지수수익률 및 변동성에 대한 영향에 관하여 알아보았다. 특히 대기오염에 하루 노출될 경우 지수수익률에 영향을 미치는 대기오염물질은 존재하지 않았으나, 5 일 이상 일산화탄소에 노출될 경우 지수수익률에 음(-)의 영향이 나타났으며 지수변동성의 경우에도 장기간 노출될수록 대기오염물질의 영향력은 크게 나타났다.

논문의 나머지 부분은 다음과 같이 구성된다. 제 2장에서는 선행 연구에 대해서 설명하고 제 3장에서는 본 논문의 연구모형 및 방법론에 대하여 설명한다. 제 4 장에서는 분석에 사용한 
한국증권학회지 제49권 3호 (2020)

자료를, 제 5장에서는 실증분석 결과를 분석하고 마지막으로 제 6장에서는 본 논문의 연 구결과를 요약한다.

\section{2. 선행연구}

\section{1 대기오염과 투자심리}

심리학자들은 투자자의 정서와 기분이 미래의 불확실한 의사결정에 영향을 미치기 때문에 감정이 불확실성 하에서 결정을 내리는데 중요한 요소라고 말한다. 즉, 기분이 좋으면 낙관적인 판단을 하고 기분이 울적하면 비관적인 선택을 한다는 것이다(Wright and Bower, 1992). 또한, 감정에 따른 인지 과정에 대한 실험을 시행한 Isen et al.(1978)은 작은 선물을 받아 기분이 향상된 소비자는 쇼핑몰의 평가를 긍정적으로 한다는 결과를 발표했다. 위와 같은 심리학 증거들은 투자심리가 낙관적인 상황은 주식시장의 가치 상승으로 이어질 것이라고 추론할 수 있게끔 도와준다.

대기오염이 심리적으로 불안하게 만들어 건강 악화나 높은 범죄율 등과 관련 있다는 연구가 있다. Lu et al.(2018)은 대기오염이 불안을 고조시켜 비윤리적 행동이 증가한다고 주장한다. 그는 미국의 패널데이터를 분석하여 대기오염과 범죄율 간의 정의 상관관계가 있음을 밝혔다. Lim et al.(2012)은 실증분석을 통해 미세먼지, 이산화질소, 오존이 증가할수록 노인의 우울증은 증가한다고 보고함으로써 대기오염이 노인의 우울증에 부정적인 영향이 있다고 주장하였다. 위 연구들은 대기오염과 심리와의 관계에 대한 직접적인 연구는 아니나, 대기 오염에 노출되면 우울증, 불안감 증가 등으로 이어질 수 있으며 대기오염과 투자자의 행동 (behavior) 간에 부정적인 영향이 있음을 추측할 수 있다.

Lee et al.(2002)과 Nofsinger(2005)는 개인투자자는 정보에 민감하므로 시장 전문분석 보다는 사회적 분위기에 영향을 많이 받으며, 사회적 분위기가 부정적일수록 투자자들 간의 의견 차이가 증가한다고 하였다. 즉, 투자심리가 낙관적이면 변동성은 감소하고 비관적이면 변동성은 증가한다는 것이다. 반면, Baker and Stein(2004)은 낙관적인 투자자들은 다른 투자자의 선택이나 정보를 과소평가하고 오직 자신의 선택을 과대평가하는 경향이 있으므로 이들이 지배하는 시장의 변동성은 높으며 수익률은 낮다고 주장하였다. 즉, 투자심리와 시장 변동성 사이에 긍정적인 상관관계가 있으며 이는 날씨가 좋으면 변동성이 증가한다는 것을 의미한다.

\section{2 대기오염과 주식시장}

2000년대 후반 이후 일부 학자들은 대기오염과 주가수익률 간의 관계에 대하여 연구하기 시작했다. Levy and Yagil(2011)은 미국의 주가지수수익률과 대기 질 지수(air quality index, $\mathrm{AQI}$ )와의 관계를 분석하였고 둘 간에 부정적인 상관관계가 있음을 발견하였다. 
Lepori(2009, 2016)는 대기오염이 이탈리아 주가수익률에 미치는 영향을 분석하였고 둘 간에 부정적인 상관관계가 있음을 밝혔다. 1990년대에 이탈리아 증권거래소가 전통적인 입회 시스템에서 전자거래시스템으로 변화됨에 따라 주식매매 방식 별 대기오염 효과를 분석할 수 있다. 분석 결과, 1990 년대 이전의 현장매매 시에는 대기오염 효과가 발견되었으나 기간 이후 전자매매 시에는 대기오염 효과가 발견되지 않았고, 이는 전자거래시스템이 대기오염 효과에 영향을 미침을 알 수 있다. 특히, 그는 미국, 스페인, 독일, 중국, 아일랜드, 캐나다, 영국, 프랑스, 호주 등 9 개 국가에서의 대기오염과 주가 지수 데이터로 추가 분석하였고, 그 결과 미국, 스페인, 독일에서도 대기오염과 주가지수수익률 간에 부정적인 상관관계가 있음을 밝힌 바 있다. Li and Peng(2016)은 대기오염으로 인한 투자자들의 우울한 기분이 중국의 2개의 주가지수수익률-상해 종합 지수와 심천 종합 지수-에 미치는 영향을 조사한 결과, 유의미한 음(-)의 상관관계를 발견하였다. Zhang et al.(2017)은 대기오염 중 연무가 주가수익률 및 변동성에 미치는 영향에 대하여 보고한 바 있다. 이들은 2010년부터 2014년까지의 기간 동안 중국 베이징의 상장회사 주가와 PM2.5 농도의 데이터를 통하여 실증분석한 결과, 연무오염이 주가수익률에는 음(-)의 상관관계를, 주가변동성에는 양(+)의 상관관계가 있음을 밝혔다.

$\mathrm{Wu}$ et al.(2018)은 중국의 개별기업 주가를 이용하여 대기오염이 현지기업의(locally headquartered firm) 주가에 미치는 영향에 대하여 분석한 결과, 대기오염은 주가 수익률과 회전율(turnover), 변동성에 대하여 음의 상관관계를, 유동성과는 양의 상관관계를 나타냈다. 높은 변동성을 띄는 주식일수록 대기오염이 주가에 미치는 영향은 더 크게 나타났다.

\section{3 투자자 유형별 거래패턴}

다수의 선행연구에서 주식시장에서의 투자자 거래패턴에 대하여 연구한 바 있다. Brock and Hommes(1998)은 이질적 경제주체 모형을 이용하여 각 투자자 유형별 금융시장에 대한 신념이 다르기 때문에 시장이 불안정해지고 주가변동성이 증가할 수 있으며, 경제주체의 무리행동이 존재할 경우에 버블에 의한 낙관론과 버블이 붕괴된 후의 비관론 사이의 혼란 스러운 자산가격 변동으로 인해 주가변동성이 급등한다고 설명한다. Park(2016)는 개인, 기관, 외국인별 무리행동과 주식시장에서의 수익률 및 변동성 간의 관계에 대하여 설명하기 위하여 각 투자자별 거래비중을 기준으로 포트폴리오 그룹을 구성하여 분석한 결과, 외국인의 거래비중이 증가할수록, 개인의 거래비중이 40 60\%인 포트폴리오 그룹에서 투자자별 무리 행동이 강하게 발생하였으며 이 때 주가변동성이 크게 증가한다고 밝힌 바 있다.

Yun and Lee(2003)는 투자자 유형별 KOSPI200 선물시장의 거래량이 선물시장의 가격 및 변동성에 미치는 영향을 분석한 결과, 외국인투자자 거래량이 선물 가격 및 변동성에 유의적으로 영향을 미치고 있음을 입증하였다. Yoo(2014)은 KOSPI200 현물시장과 선물 시장 및 옵션시장에서의 투자자 유형별 거래량이 주식시장의 수익률 및 변동성에 미치는 교차 시장 간 효과를 분석한 바 있다. 
한국증권학회지 제49권 3호 (2020)

Khil et al.(2009)은 투자자 유형별 위험회피 효용함수에 따른 거래패턴의 차이에 의해 비대칭 변동성이 발생되므로 투자자별 거래비중이 비대칭 변동성에 미치는 영향을 분석하여 위험회피형 투자자는 주가등락에 따라 거래패턴이 다를 것이므로 상대적으로 위험회피 성향인 개인투자자의 비중이 높을수록 비대칭 변동성이 증가하고 기관투자자 및 외국인투자자의 비중이 높을수록 비대칭 변동성은 감소하는 결과를 밝힌 바 있다.

일부 학자들은 투자자 유형별 거래패턴을 연구하여 개인과 기관, 외국인투자자 간 군집 행동이나 추세추종 등 상호간에 어떠한 영향을 미치는지 알아보고자 하였다. Yun(1994)은 1992년 1월부터 1993년 6월까지의 자료를 이용하여 VAR모형을 추정하였고 외국인투자자의 매수거래량이 국내 개인 및 기관투자자의 매수거래량에 영향을 주는 것이 아니라 기관투자자의 매수거래량이 외국인투자자의 매수에 영향을 주는 것을 발견하였다. Choe et al.(2001)은 1996년 12월부터 1998년 11월까지의 투자자 유형별 거래패턴을 분석하였고 개인 및 기관 투자자들이 외국인투자자에 비해 더 유용한 투자정보를 가지고 있음을 발견했다. Kim(2001)은 1996년 12월부터 1999년 12월까지의 외국인별 월간 종목보유자료와 투자자유형별 일간 종목거래자료를 이용하여 외국인의 주식투자행태를 연구하여 비거주외국인은 거주외국인에 비해, 개인투자자는 기관투자자에 비해 더 높은 성향의 군집행동을 보임을 밝혔다.

\section{3. 연구모형}

본 장에서는 대기오염으로 인한 투자심리 변화가 국내 코스피시장의 수익률 및 변동성에 미치는 직접적인 영향을 알아보고 더 나아가서 투자자 유형별 거래비중을 통한 환경요인이 미치는 간접적인 영향을 분석한다. 분석은 다변량 OLS((ordinary least squares) 회귀분석을 수행하였으며 각 회귀분석 식은 제 4장에서 확인할 수 있다.

\section{1 수익률 및 변동성}

수익률은 코스피지수의 당일 종가와 전일 종가의 비율에 로그 값을 취하여 계산한다. 이 때 $\mathrm{S}_{\mathrm{t}}$ 는 $\mathrm{t}$ 일의 종가이며 다음과 같이 계산한다.

$$
\mathrm{R}_{\mathrm{t}}=100 \times\left\{\log \left(\mathrm{S}_{\mathrm{t}}\right)-\log \left(\mathrm{S}_{\mathrm{t}-1}\right)\right\}
$$

변동성은 역사적변동성(Historical volatility)과 범위기반변동성(Ranged based volatility)으로 산출한다. 역사적변동성은 과거 일정 기간의 로그수익률의 표준편차를 계산하여 변동성을 추정하는 방법으로 주식시장에 외부 충격이 가해지더라도 단기간에 평균으로 회귀하려는 특성 때문에(Poterba and Summers, 1988) 예측력이 우수하고 간편하다는 장점이 있다. $\mathrm{R}_{\mathrm{t}}$ 는 $\mathrm{t}$ 일의 일별 로그수익률, $\overline{\mathrm{R}}_{\mathrm{t}, \mathrm{n}}$ 는 $\mathrm{t}$ 일로부터 과거 $\mathrm{n}$ 일까지의 일별 로그수익률의 표본 평균 이며 과거 기간 $\mathrm{n}$ 은 월 거래일수인 23일로, $\mathrm{N}$ 은 연 거래일수인 252 일을 기준으로 계산 하였다. 


$$
\mathrm{Vol}_{\mathrm{h}, \mathrm{t}}=\sqrt{\mathrm{N}} \times \sqrt{\frac{\sum_{\mathrm{t}=1}^{\mathrm{n}}\left(\mathrm{R}_{\mathrm{t}}-\overline{\mathrm{R}}_{\mathrm{t}, \mathrm{n}}\right)^{2}}{\mathrm{n}-1}}
$$

범위기반변동성은 기초자산의 종가, 시가, 고가, 저가의 정보를 모두 활용하여 측정한 변동성으로 Parkinson(1980)에 의해 최초 연구되었다. Parkinson(1980)은 기초자산의 고가와 저가만 이용하여 변동성을 측정하였다(이하 PK 범위기반변동성). 그러나 매수-매도 호가에 차이가 있는 경우에 평균 스프레드에 의해 가격이 과대평가 또는 과소평가될 수 있다는 단점이 있는데, 이에 Garman and Klass(1980)은 PK 범위기반변동성 추정의 단점을 보완하기 위해 기초자산의 고가와 저가, 시가와 종가 모두를 포함하는 GK 범위기반변동성을 제안 하였다.

본 연구에서는 시가와 종가 사이의 수익률 제곱의 가중평균을 이용하여 산출한 GK범위 기반변동성의 추정치를 산출하여 분석하고자 한다. $\mathrm{h}_{\mathrm{t}}, \mathrm{l}_{\mathrm{t}}, \mathrm{O}_{\mathrm{t}}, \mathrm{c}_{\mathrm{t}}$ 는 $\mathrm{t}$ 일의 고가, 저가, 시가, 종가를 의미하며, n은 월 거래일수인 23일, $\mathrm{N}$ 은 연 거래일수인 252일이다.

$$
\operatorname{Vol}_{\mathrm{GK}, \mathrm{t}}=\sqrt{\frac{\mathrm{N}}{\mathrm{n}} \sum_{\mathrm{t}=1}^{\mathrm{n}}\left[\frac{1}{2}\left(\log \frac{\mathrm{h}_{\mathrm{t}}}{\mathrm{l}_{\mathrm{t}}}\right)^{2}-(2 \ln 2-1)\left(\log \frac{\mathrm{c}_{\mathrm{t}}}{\mathrm{o}_{\mathrm{t}}}\right)^{2}\right]}
$$

\section{2 투자자 유형별 거래비중}

주식시장에서의 투자자 유형은 개인, 기관, 외국인투자자로 나뉠 수 있다. 효율적 시장 가설에 의하면 주식시장의 총 거래량(Total Volume, TV)은 총매수거래량 $\left(\mathrm{TV}_{\mathrm{B}}\right)$ 또는 총 매도거래량 $\left(\mathrm{TV}_{\mathrm{S}}\right)$ 과 일치한다. 본 연구에서는 각 투자자 유형별 거래량을 주식시장의 총 거래량으로 나눈 값을 투자자 유형별 거래비중(Trading ratio, TR)으로 정의하여 ${ }^{2)}$ 다음과 같이 6 가지 거래비중을 통한 대기오염물질이 주식시장에 미치는 영향을 분석하고자 한다. 이 때 $\mathrm{TR}_{\mathrm{l}, \mathrm{n}}$ 는 투자자 유형별 거래비중, $\mathrm{V}_{\mathrm{l}, \mathrm{n}}$ 는 투자자 유형별 거래량이며, 1 은 매수(B), 매도(S) 등 거래형태를, n은 개인(ind), 기관(ins), 외국인(for) 등 투자자유형이다.

$$
\mathrm{TR}_{1, \mathrm{n}}=\frac{\mathrm{V}_{\mathrm{l}, \mathrm{n}}}{\mathrm{TV}_{1}} \times 100=\frac{\mathrm{V}_{\mathrm{l}, \mathrm{n}}}{\mathrm{TV}} \times 100
$$

\section{4. 자료}

본 절에서는 대기오염이 한국 코스피지수의 수익률 및 변동성에 미치는 직접적인 영향과 투자자 유형별 거래비중을 통한 대기오염이 미치는 간접적인 영향에 대하여 분석한다. 연구에서

2) 투자자 유형별 거래비중은 Kho and $\operatorname{Kim}(2017)$ 의 방법론에 따름. 
한국증권학회지 제49권 3호 (2020)

사용한 대기환경기준물질 자료는 한국환경공단 에어코리아(http://www.airkorea.or.kr)에서," 국내 코스피시장의 일별 가격정보 및 투자자 유형별 거래량 자료는 데이터 가이드 5 에서 얻을 수 있으며, 분석기간은 2015년 1월 1일부터 2018년 12월 31일까지이다. ${ }^{4)}$ 관찰기간 중 미세먼지 농도에서 극단치가 발생하였으며 원인은 황사인 것으로 추정된다. ${ }^{5)}$ 황사가 발생한 날은 총 38일이며 극단치를 제거하면 편의가 발생할 수 있으므로 발생한 극단치는 조정이 필요하다. 즉, 황사 발생일의 미세먼지 농도가 황사가 없는 날의 미세먼지 최대농도를 초과할 경우에 식 (5)와 같이 조정하여 분석한다.

극단치 조정 $=$ 황사가 없는 날의 미세먼지 최대값+황사가 없는 날의 미세먼지 표준편차

$$
\times \frac{\text { 극단치-황사가 없는 날의 미세먼지 최대값 }}{\text { 극단치의 최대값-황사가 없는 날의 미세먼지 최대값 }}
$$

본 절에서 분석하고자 하는 대기오염물질은 미세먼지 $\left(\mathrm{PM}_{10}\right)$, 초미세먼지 $\left(\mathrm{PM}_{2.5}\right)$, 오존 $\left(\mathrm{O}_{3}\right)$, 이산화질소 $\left(\mathrm{NO}_{2}\right)$, 일산화탄소 $(\mathrm{CO})$, 아황산가스 $\left(\mathrm{SO}_{2}\right)$ 등 6 개로 구분하며 투자자 유형은 개인, 기관, 외국인으로 나눌 수 있다. 또한 종속변수로 사용한 수익률은 당일 코스피 지수 종가를 사용한 로그수익률의 값을 사용하며, 변동성은 역사적변동성, GK 범위기반변동성의 방식으로 계산하였다.

미세먼지 $\left(\mathrm{PM}_{10}\right)$ 는 입자의 크기가 $10 \mu \mathrm{m}$ 이하인 먼지이며 초미세먼지 $\left(\mathrm{PM}_{2.5}\right)$ 는 입자의 크기가 $2.5 \mu \mathrm{m}$ 이하의 먼지로 규정한다. 오존 $\left(\mathrm{O}_{3}\right)$ 은 대기중에 배출된 질소산화물 $(\mathrm{NOx})$ 과 휘발성 유기화합물(Volatile Organic Compounds) 등이 자외선과 광화학 반응을 일으켜 생성되는 기체로 오존에 반복 노출 시 폐에 심각한 문제를 초래할 수 있다. 이산화질소 $\left(\mathrm{NO}_{2}\right)$ 는 대기중의 일산화질소의 산화에 의해 발생하며, 대기 중에서 휘발성유기화합물과 반응하여 오존을 생성하는 역할을 한다. 이산화질소에 지속적으로 노출되면 만성 기관지염, 폐렴 등이 발병할 수 있다. 일산화탄소(CO)는 연료속의 탄소성분이 불완전 연소되었을 때 발생하는 무색, 무취의 유독성 가스이다. 아황산가스 $\left(\mathrm{SO}_{2}\right)$ 는 황산화물의 일종으로 석탄, 석유 등의 화석연료가 연소될 때 인위적으로 배출되며 호흡기계 질환을 일으키는 것으로 알려져 있다.

분석 시 각 변수간 크기를 맞추기 위하여 데이터를 조정하였다. ${ }^{6)}$ 또한 대기오염물질 변수는

3 ) 에어코리아에서는 전국 365 개의 지점에서 도시 대기상태를 측정한다. 본 연구에서는 서울에서 측정한 365 개의 측정치의 평균값을 사용한다. 장애 등의 사유로 측정이 불가능한 경우의 데이터는 삭제한다.

4) 환경정책기본법시행령<시행일: 2015.1.1> <별표> 환경기준(제2조 관련) 시행 이후로 초미세먼지 $\left(\mathrm{PM}_{2.5}\right)$ 측정이 시작되었으므로 본 연구의 분석기간은 2015년 1월 1일부터 2018년 12월 31일 까지로 한다.

5) 황사는 미세먼지의 원인 중 하나이므로, 황사가 심한 날 미세먼지 값에 극단치가 발생하였다.

6) 각 변수들의 평균, 표준편차 등 크기를 맞추기 위하여 오존과 이산화질소에는 1,000 을, 일산화탄소에는 100 을, 아황산가스에는 10,000 을 곱하여 조정한다. 
계절성이 존재하므로 이를 제거하기 위하여 일별 자료에서 계절 평균값그를 차감하여 분석 하였다. 이 때 $A P_{t}^{0}$ 는 대기오염물질의 일별 자료이며, $\overline{A P}_{\text {season }}$ 는 $\mathrm{t}$ 가 속한 계절의 3 개월 평균값을 의미한다.

$$
A P_{t}=A P_{t}^{0}-\overline{A P}_{\text {season }}
$$

주초에 특이한 수익률 패턴을 나타내는 계절효과 현상을 제거하기 위하여 월요일은 더미 변수를 생성하여 통제하였고 대기오염과 상관관계가 높은 날씨 또한 통제하여 분석하였다. 또한 과거 시장수익률은 투자심리에 영향을 미치는 중요한 요소이므로(Brown and Cliff, $2004)$, 전월 코스피지수의 평균수익률 $\left(\mathrm{R}_{\mathrm{m}}\right)$ 을 통제하였다. 분석에 사용한 변수에 대한 설명은 <표 1>에, 주요 변수에 대한 시계열 도표는 <그림 1>에, 주요 변수 간 상관계수는 <표 2>에 기술하였다. 역사적변동성과 범위기반변동성은 오존과 이산화질소, 아황산가스와의 상관관계가 높게 나타났다. 또한 오존을 제외한 나머지 5 가지 대기오염물질 간에 높은 상관관계가 있음을 알 수 있었고 6 가지 독립변수를 모두 포함하여 회귀분석시에는 다중 공선성 문제가 발생할 수 있다. 이에 본 연구에서는 하나의 대기오염물질이 종속변수에 미치는 영향에 대하여 분석할 예정이다.

〈표 1〉변수 설명

\begin{tabular}{|c|c|c|c|c|c|}
\hline 구분 & 변수명 & 설명 & 구분 & 변수명 & 설명 \\
\hline 수익률 & $\mathrm{R}_{\mathrm{t}}$ & 로그수익률 & 통제변수 & $\mathrm{R}_{\mathrm{m}}$ & 전월 시장수익률 \\
\hline 변동성 & Volh,t $_{\text {t }}$ & 역사적변동성 & & Drain & 강수더미 \\
\hline & $\mathrm{Vol}_{\mathrm{GK}, \mathrm{t}}$ & GK 범위기반변동성 & & Cloud & 구름 양 \\
\hline 거래비중 & $\mathrm{TR}_{\mathrm{B} \text {,ind }}$ & 개인 매수비중 & & Solar & 일사량 \\
\hline & $\mathrm{TR}_{\mathrm{S} \text {, ind }}$ & 개인 매도비중 & & Temp & 기온 \\
\hline & $\mathrm{TR}_{\mathrm{B}, \text { ins }}$ & 기관 매수비중 & & DMon & 월요일 더미 \\
\hline & $\mathrm{TR}_{\mathrm{S} \text {,ins }}$ & 기관 매도비중 & & & \\
\hline & $\mathrm{TR}_{\mathrm{B}, \text { for }}$ & 외국인 매수비중 & & & \\
\hline & $\mathrm{TR}_{\mathrm{S}, \text { for }}$ & 외국인 매도비중 & & & \\
\hline 대기오염물질 & $\mathrm{PM}_{10}$ & 조정 미세먼지 & & & \\
\hline & $\mathrm{PM}_{2.5}$ & 조정 초미세먼지 & & & \\
\hline & $\mathrm{O}_{3}$ & 조정 오존 & & & \\
\hline & $\mathrm{NO}_{2}$ & 조정 이산화질소 & & & \\
\hline & $\mathrm{CO}$ & 조정 일산화탄소 & & & \\
\hline & $\mathrm{SO}_{2}$ & 조정 아황산가스 & & & \\
\hline
\end{tabular}

7) 계절평균은 계절에 따라 네 가지로 구분하여-봄( $3,4,5$ 월), 여름( $6,7,8$ 월), 가을( $9,10,11$ 월), 겨울(12, 1, 2월)-관찰월이 속한 계절의 3 개월 평균값을 계산하여 차감한다. 
한국증권학회지 제49권 3호 (2020)

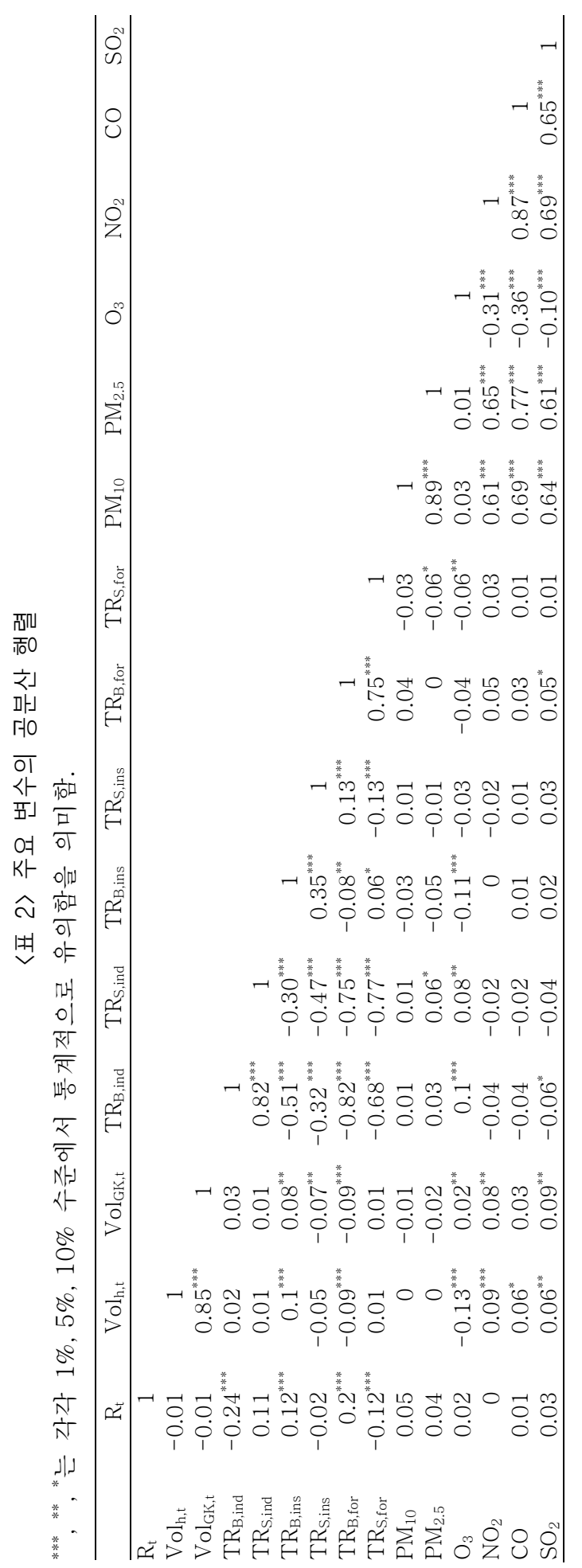


Air Pollution, Stock Return, and Volatility

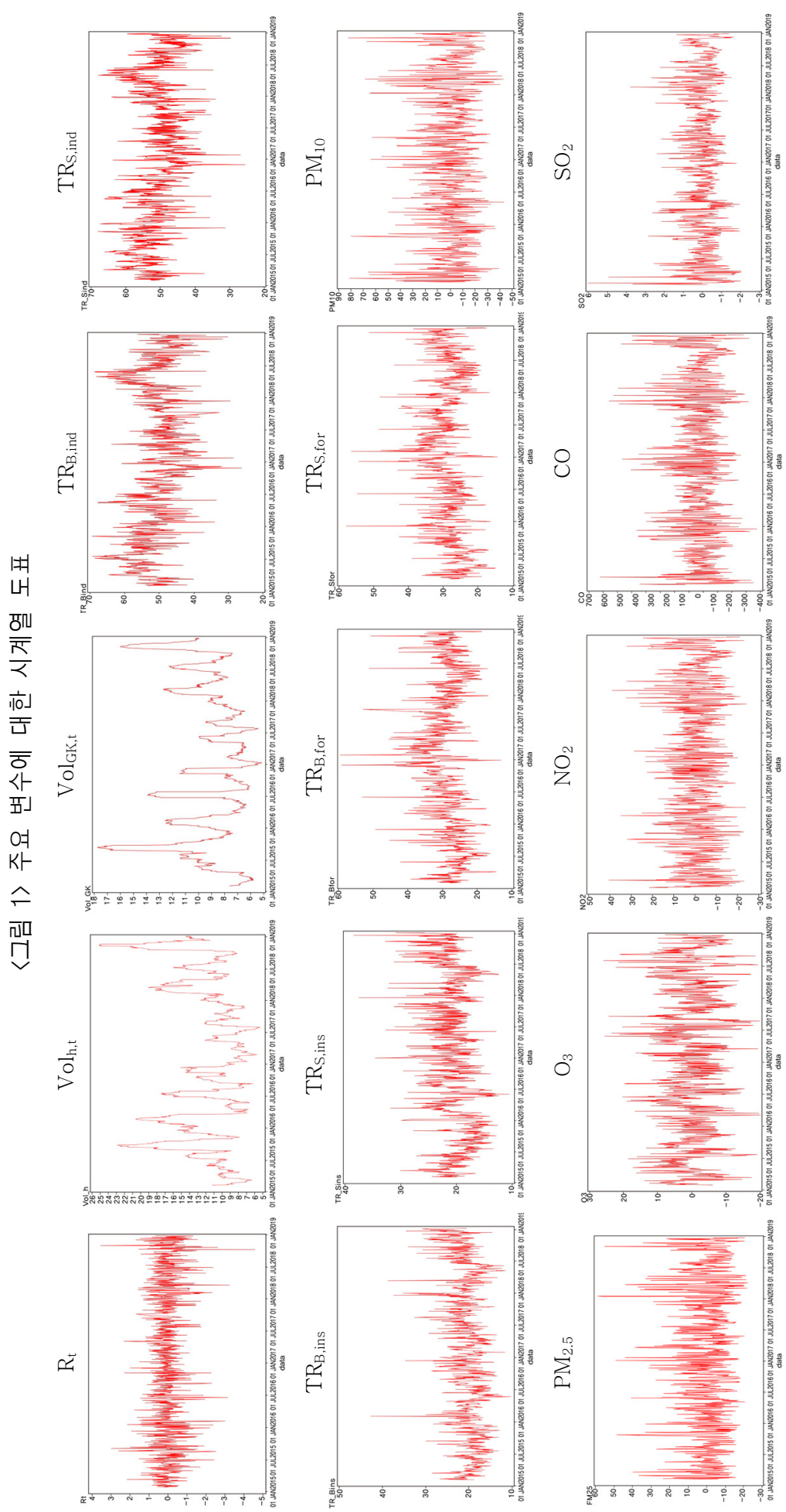




\section{5. 실증분석}

\section{1 기술통계분석}

<표 3〉은 주요 변수에 대한 기술통계분석을 보여준다. 역사적변동성의 평균과 표준편차가 범위기반변동성보다 큰 것을 확인할 수 있다. 투자자 유형별 거래비중의 평균은 개인 $50.83 \%$, 기관 $20.56 \%$, 외국인 $28.79 \%$ 이며 다른 유형과 비교하여 개인투자자의 거래비중의 평균이 약 2.5 배 높게 나타나고 있다. 앞서 대기오염물질 변수는 계절조정 하였으므로 각 변수의 평균은 0 에 가까움을 알 수 있다.

〈표 3〉 주요 변수의 기초 통계량

\begin{tabular}{lrrrrrrr}
\hline \multicolumn{1}{c}{ 변수명 } & \multicolumn{1}{c}{ 평균 } & 표준편차 & 최소값 & 최대값 & 왜도 & 첨도 & 관측수 \\
\hline $\mathrm{R}_{\mathrm{t}}$ & 0 & 0.78 & -4.54 & 3.47 & -0.53 & 2.78 & 960 \\
Vol $_{\mathrm{h}, \mathrm{t}}$ & 11.71 & 3.82 & 5.4 & 25.14 & 0.97 & 0.54 & 960 \\
Vol $_{\mathrm{GK}, \mathrm{t}}$ & 9.01 & 2.5 & 5.14 & 17.76 & 1.16 & 1.28 & 960 \\
$\mathrm{TR}_{\mathrm{B}, \text { ind }}$ & 50.66 & 6.5 & 26.25 & 69.15 & -0.08 & 0.37 & 960 \\
$\mathrm{TR}_{\mathrm{S}, \text { ind }}$ & 51 & 6.17 & 25.43 & 67.91 & -0.14 & 0.48 & 960 \\
$\mathrm{TR}_{\mathrm{B}, \text { ins }}$ & 20.46 & 3.77 & 10.42 & 42.67 & 0.92 & 2.61 & 960 \\
$\mathrm{TR}_{\mathrm{S}, \text { ins }}$ & 20.66 & 3.66 & 10.64 & 38.48 & 0.68 & 1.4 & 960 \\
$\mathrm{TR}_{\mathrm{B}, \text { for }}$ & 28.88 & 5.6 & 13.17 & 59.82 & 0.96 & 2.92 & 960 \\
$\mathrm{TR}_{\mathrm{S}, \text { for }}$ & 28.69 & 5.47 & 14.37 & 58.02 & 0.84 & 2.65 & 960 \\
$\mathrm{PM}_{10}$ & 0.06 & 19.48 & -43.32 & 82.55 & 1.01 & 1.79 & 960 \\
$\mathrm{PM}_{2.5}$ & 0.04 & 12.35 & -22.3 & 58.85 & 1.16 & 2.11 & 960 \\
$\mathrm{O}_{3}$ & 0.01 & 7.72 & -20 & 25.9 & 0.19 & 0.16 & 960 \\
$\mathrm{NO}_{2}$ & -0.01 & 10.42 & -24.01 & 40.54 & 0.39 & 0.2 & 960 \\
$\mathrm{CO}$ & -0.05 & 14.24 & -37.31 & 62.69 & 0.74 & 1.32 & 960 \\
$\mathrm{SO}_{2}$ & -0.06 & 8.67 & -20.41 & 59.97 & 1.14 & 3.94 & 960 \\
\hline
\end{tabular}

\section{2 대기오염물질이 지수수익률 및 변동성에 미치는 영향}

대기오염물질과 지수수익률 및 변동성 간의 회귀분석 식은 <표 $4>$ 와 같으며 분석 결과는 <표 5> <표 7>에서 확인할 수 있다. $\operatorname{Dep}_{\mathrm{i}, \mathrm{t}}$ 는 수익률 $\left(\mathrm{R}_{\mathrm{t}}\right)$, 역사적변동성 $\left(\mathrm{Vol}_{\mathrm{h}, \mathrm{t}}\right)$, 범위기반 변동성 $\left(\mathrm{Vol}_{\mathrm{GK}, \mathrm{t}}\right)$ 등 종속변수를 나타내며 설명변수는 $\mathrm{AP}_{\mathrm{j}, \mathrm{t}}$ (대기오염물질 변수)이며 통제변수로는 $\mathrm{R}_{\mathrm{m}, \mathrm{t}}$ (전월 시장수익률), $\mathrm{W}_{\mathrm{k}, \mathrm{t}}$ (날씨 변수), $\mathrm{DMon}_{\mathrm{t}}$ (요일 더미변수)를 사용하였다. 이 때, $\mathrm{j}$ 는 $\mathrm{PM}_{10}$, $\mathrm{PM}_{2.5}, \mathrm{O}_{3}, \mathrm{NO}_{2}, \mathrm{CO}, \mathrm{SO}_{2}$ 등 6종류의 대기오염물질을, $\mathrm{k}$ 는 강수(Drain), 구름 양(Cloud), 일사량(Solar), 기온(Temp) 등 날씨를 의미한다. 모형 0은 대기오염물질이 없는 대조군이고 모형 1 모형 6은 각 대기오염물질 변수에 대한 회귀분석모형이다.

분석 결과, 대기오염물질이 지수수익률에 미치는 영향은 통계적으로 유의한 값을 보이지는 않았다. 반면, 역사적변동성은 초미세먼지와 유의한 음(-)의 상관관계를, 범위기반변동성은 미세먼지와 초미세먼지와 유의한 음(-)의 상관관계를 보였다. 이는 초미세먼지의 농도가 높을수록 역사적변동성과 범위기반변동성은 감소하며, 미세먼지의 농도가 높을수록 범위 기반변동성이 감소함을 의미한다. 
Air Pollution, Stock Return, and Volatility

〈표 4〉모형의 회귀분석 식

\begin{tabular}{lc}
\hline 모형번호 & 회귀분석 식 \\
\hline 0 & $\operatorname{Dep}_{\mathrm{i}, \mathrm{t}}=\alpha_{0}+\alpha_{1} \mathrm{R}_{\mathrm{m}, \mathrm{t}}+\sum_{\mathrm{k}=2}^{5} \alpha_{k} \mathrm{~W}_{\mathrm{k}, \mathrm{t}}+\alpha_{6} \mathrm{DMon}_{\mathrm{t}}+\varepsilon_{\mathrm{t}}$, \\
\hline $1 \sim 6$ & $\mathrm{Dep}_{\mathrm{i}, \mathrm{t}}=\alpha_{0}+\alpha_{1} \mathrm{AP}_{\mathrm{j}, \mathrm{t}}+\alpha_{7} \mathrm{R}_{\mathrm{m}, \mathrm{t}}+\sum_{\mathrm{k}=8}^{11} \alpha_{\mathrm{k}} \mathrm{W}_{\mathrm{k}, \mathrm{t}}+\alpha_{12} \mathrm{DMon}_{\mathrm{t}}+\varepsilon_{\mathrm{t}}$ \\
\hline
\end{tabular}

〈표 5〉대기오염물질이 지수수익률에 미치는 영향

\begin{tabular}{|c|c|c|c|c|c|c|c|}
\hline $\mathrm{R}_{\mathrm{t}}$ & 0 & 1 & 2 & 3 & 4 & 5 & 6 \\
\hline$\overline{a_{0}}$ & 0.09 & 0.09 & 0.09 & 0.11 & 0.1 & 0.09 & 0.09 \\
\hline
\end{tabular}

$\mathrm{PM}_{10}$

0

$\mathrm{PM}_{2.5}$

$\mathrm{O}_{3}$

$\mathrm{NO}_{2}$

$\mathrm{CO}$

$\mathrm{SO}_{2}$

$\mathrm{R}_{\mathrm{m}}$

Drain

Cloud

Solar

Temp

DMon

$\operatorname{Adj}-R^{2}$

(a)

0

\begin{tabular}{rrrrrrr} 
& & & 0 & 0 & 0 \\
0 & 0 & 0 & 0 & 0 & 0 & 0 \\
-0.12 & -0.1 & -0.11 & -0.12 & -0.12 & -0.12 & -0.11 \\
0 & -0.01 & -0.01 & 0 & 0 & 0 & 0 \\
0 & 0 & 0 & 0 & 0 & 0 & 0 \\
0 & 0 & 0 & 0 & 0 & 0 & 0 \\
-0.09 & -0.09 & -0.09 & -0.09 & -0.09 & -0.09 & -0.09 \\
-0.0011 & -0.0007 & -0.0012 & -0.0019 & -0.0018 & -0.0021 & -0.0019 \\
\hline
\end{tabular}

〈표 6〉대기오염물질이 역사적변동성에 미치는 영향

***, ${ }^{* *},{ }^{*}$ 는 각각 $1 \%, 5 \%, 10 \%$ 수준에서 통계적으로 유의함을 의미함.

\begin{tabular}{|c|c|c|c|c|c|c|c|}
\hline $\mathrm{Vol}_{\mathrm{h}, \mathrm{t}}$ & 0 & 1 & 2 & 3 & 4 & 5 & 6 \\
\hline$\overline{a_{0}}$ & $12.40^{* * * *}$ & $12.41^{* * *}$ & $12.41^{* * *}$ & $12.24^{* * *}$ & $12.35^{* * *}$ & $12.40^{* * * *}$ & $12.38^{* * *}$ \\
\hline $\mathrm{PM}_{10}$ & & -0.01 & & & & & \\
\hline $\mathrm{PM}_{2.5}$ & & & $-0.02^{* *}$ & & & & \\
\hline $\mathrm{O}_{3}$ & & & & -0.02 & & & \\
\hline $\mathrm{NO}_{2}$ & & & & & 0.02 & & \\
\hline $\mathrm{CO}$ & & & & & & 0 & \\
\hline $\mathrm{SO}_{2}$ & & & & & & & 0.01 \\
\hline $\mathrm{R}_{\mathrm{m}}$ & $-0.66^{* * *}$ & $-0.66^{* * *}$ & $-0.66^{* * *}$ & $-0.65^{* * *}$ & $-0.65^{* * *}$ & $-0.66^{* * *}$ & $-0.65^{* * *}$ \\
\hline Drain & -0.21 & -0.26 & -0.26 & -0.18 & -0.12 & -0.21 & -0.16 \\
\hline Cloud & 0.05 & 0.06 & 0.06 & 0.05 & 0.04 & 0.05 & 0.05 \\
\hline Solar & -0.02 & -0.03 & -0.03 & -0.01 & -0.02 & -0.02 & -0.02 \\
\hline Temp & $-0.03^{* *}$ & $-0.03^{* *}$ & $-0.03^{* *}$ & $-0.03^{* *}$ & $-0.03^{* *}$ & $-0.03^{* *}$ & $-0.03^{* *}$ \\
\hline DMon & 0.12 & 0.12 & 0.13 & 0.11 & 0.13 & 0.12 & 0.13 \\
\hline $\operatorname{Adj}-R^{2}$ & $0.3432^{* * * *}$ & $0.3443^{* * *}$ & $0.3458^{* * *}$ & $0.3444^{* * * *}$ & $0.3441^{* * * *}$ & $0.3426^{* * * *}$ & $0.3430^{* * * *}$ \\
\hline
\end{tabular}


〈표 7〉 대기오염물질이 범위기반변동성에 미치는 영향 *** ${ }^{* *},{ }^{*}$ 는 각각 $1 \%, 5 \%, 10 \%$ 수준에서 통계적으로 유의함을 의미함.

\begin{tabular}{lccccccc}
\hline \multicolumn{1}{c}{ Vol $_{\mathrm{GK}, \mathrm{t}}$} & 0 & 1 & 2 & 3 & 4 & 5 & \multicolumn{1}{c}{6} \\
\hline $\mathrm{a}_{0}$ & $8.91^{* * * *}$ & $8.92^{* * *}$ & $8.93^{* * *}$ & $8.87^{* * *}$ & $8.91^{* * *}$ & $8.96^{* * * *}$ & $8.89^{* * * *}$ \\
$\mathrm{PM}_{10}$ & & $-0.01^{* *}$ & & & & & \\
$\mathrm{PM}_{2.5}$ & & & $-0.02^{* * *}$ & & & & \\
$\mathrm{O}_{3}$ & & & -0.01 & & & \\
$\mathrm{NO}_{2}$ & & & & & & $-0.01^{*}$ & \\
$\mathrm{CO}$ & & & & & & \\
$\mathrm{SO}_{2}$ & & & & & & & \\
$\mathrm{R}_{\mathrm{m}}$ & -0.43 & -0.43 & -0.43 & -0.42 & -0.43 & -0.43 & -0.42 \\
Drain & -0.2 & -0.25 & -0.25 & -0.19 & -0.19 & -0.24 & -0.15 \\
Cloud & 0.02 & 0.03 & 0.03 & 0.02 & 0.02 & 0.02 & 0.02 \\
Solar & -0.01 & -0.01 & -0.01 & 0 & 0 & -0.01 & 0 \\
Temp & $0.02^{* *}$ & $0.02^{* *}$ & $0.02^{* * *}$ & $0.02^{* *}$ & $0.02^{* *}$ & $0.02^{* *}$ & $0.02^{* * *}$ \\
DMon & 0.02 & 0.03 & 0.03 & 0.02 & 0.02 & 0.01 & 0.03 \\
Adj-R & $0.3355^{* * *}$ & $0.3379^{* * *}$ & $0.3405^{* * *}$ & $0.3351^{* * *}$ & $0.3348^{* * *}$ & $0.3368^{* * *}$ & $0.3361^{* * *}$ \\
\hline
\end{tabular}

\section{3 대기오염물질이 투자자별 거래비중에 미치는 영향}

본 절에서는 대기오염물질이 투자자 유형별 거래비중에 미치는 영향을 알아보고자 한다. 분석에 사용한 회귀분석 식은 <표 8>과 같으며 분석 결과는 <표 9> <표 $14>$ 에서 확인 할 수 있다. $\mathrm{TR}_{\mathrm{ln}, \mathrm{t}}$ 는 투자자 유형별 거래비중을 나타내는 변수이며 1 은 매수(B), 매도(S) 등 거래형태를, $\mathrm{n}$ 은 개인(ind), 기관(ins), 외국인(for) 등 투자자 유형을 의미한다. 설명변수로 사용한 $\mathrm{AP}_{\mathrm{j}, \mathrm{t}}$ 은 대기오염물질 변수를 나타내며 $\mathrm{j}$ 는 $\mathrm{PM}_{10}, \mathrm{PM}_{2.5}, \mathrm{O}_{3}, \mathrm{NO}_{2}, \mathrm{CO}, \mathrm{SO}_{2}$ 등 6 종류의 대기오염물질이다. 통제변수로는 $\mathrm{R}_{\mathrm{m}, \mathrm{t}}$ (전월 시장수익률), $\mathrm{W}_{\mathrm{k}, \mathrm{t}}$ (날씨 변수), $\mathrm{DMon}_{\mathrm{t}}$ (요일 더미 변수)를 사용하였으며 모형 1 모형 6은 각 대기오염물질 변수에 대한 회귀분석 모형이다.

〈표 8〉모형의 회귀분석 식

\begin{tabular}{lc}
\hline 모형번호 & 회귀분석 식 \\
\hline 0 & $\mathrm{TR}_{\mathrm{l}, \mathrm{n}, \mathrm{t}}=\alpha_{0}+\alpha_{\mathrm{j}} \mathrm{AP}_{j, \mathrm{t}}+\alpha_{7} R_{m, t}+\sum_{\mathrm{k}=8}^{11} \alpha_{\mathrm{k}} W_{k, t}+\alpha_{12} \mathrm{DMon}_{\mathrm{t}}+\varepsilon_{\mathrm{t}}$ \\
\hline $1 \sim 6$ & $\mathrm{TR}_{\mathrm{i}, \mathrm{n}, \mathrm{t}}=\alpha_{0}+\alpha_{\mathrm{j}} \sum_{\mathrm{j}=1}^{6} \mathrm{AP}_{\mathrm{j}, \mathrm{t}}+\alpha_{7} \mathrm{R}_{\mathrm{m}, \mathrm{t}}+\sum_{\mathrm{k}=8}^{11} \alpha_{k} \mathrm{~W}_{\mathrm{k}, \mathrm{t}}+\alpha_{12} \mathrm{DMon}_{\mathrm{t}}+\varepsilon_{\mathrm{t}}$ \\
\hline
\end{tabular}

대기오염물질이 투자자별 거래비중에 미치는 영향은 기관투자자의 매수비중과 외국인 투자자의 매도비중의 경우에서만 유의한 결과가 나타났다. 즉, 초미세먼지의 농도가 높아지면 기관투자자의 매수비중과 외국인투자자의 매도비중은 감소하는 결과가 나타났으며 개인투자자의 거래비중에 영향을 미치고 외국인투자자의 거래비중과는 무관할 것이라고 예상한 우리의 가설과 반대되는 결과를 보였다. 이는 비정보거래자라고 알려진 개인투자자와는 달리 기관 투자자는 대기오염 또한 정보로 받아들여 맑은 날보다 대기오염이 심한 날에 매수비중이 감소한다고 할 수 있다. 그러나 대기오염물질이 외국인투자자의 거래비중에 영향을 미치는 결과는 현지날씨가 외국인투자자의 기분이나 의사결정에 영향을 미치지 않으므로 날씨 효과가 
Air Pollution, Stock Return, and Volatility

발생하지 않는다고 주장한 Kang et al.(2010)의 연구와 상반되는 결과이다. 그러나 외국인들이 거래패턴을 연구한 $\operatorname{Kim}(2001)$ 은 비거주외국인의 정보열위가 군집행동을 강화시킨다고 주장한 바 있다. 군집 행동이란 특정 집단내의 투자자들이 서로의 투자선택을 모방하여 투자하는 현상으로, 정보의 비대칭성에 의해 정보 열위에 있는 비거주외국인들은 더 높은 성향의 군집 행동을 보일 것으로 예측할 수 있다(Kim, 2001). 즉, 초미세먼지의 농도가 외국인투자자의 거래비중에 영향을 미친 사실은 현지 대기오염 정보가 영향을 미쳤다기 보다 군집행동에 의해 영향을 받았다고 추론할 수 있다. 본 절의 분석결과를 통해 대기오염물질이 투자자 유형별 거래비중에 상이한 영향을 미친다는 점을 확인할 수 있었다. 향후 투자자별 거래비중을 통해 대기오염물질이 지수수익률 및 변동성에 미치는 간접적인 영향을 알아보고자 한다.

〈표 9〉대기오염물질이 개인투자자의 매수비중에 미치는 영향

***, ${ }^{* *},{ }^{*}$ 는 각각 $1 \%, 5 \%, 10 \%$ 수준에서 통계적으로 유의함을 의미함.

\begin{tabular}{lcccccc}
\hline \multicolumn{1}{c}{$\mathrm{TR}_{\mathrm{B}, \text { ind }}$} & 1 & 2 & 3 & 4 & 5 & \multicolumn{1}{c}{6} \\
\hline $\mathrm{a}_{0}$ & $46.43^{* * *}$ & $46.41^{* * *}$ & $46.68^{* * *}$ & $46.46^{* * *}$ & $46.44^{* * *}$ & $46.48^{* * *}$ \\
$\mathrm{PM}_{10}$ & 0 & & & & & \\
$\mathrm{PM}_{2.5}$ & & 0.02 & & & & \\
$\mathrm{O}_{3}$ & & & & & \\
$\mathrm{NO}_{2}$ & & & & & & \\
$\mathrm{CO}$ & & & & & \\
$\mathrm{SO}_{2}$ & & & & & & -0.01 \\
$\mathrm{R}_{\mathrm{m}}$ & 0.07 & 0.07 & 0.06 & 0.06 & 0.07 & 0.06 \\
Drain & $2.19^{* * * *}$ & 2.27 & 2.15 & 2.13 & 2.19 & 2.06 \\
Cloud & 0.15 & 0.13 & 0.14 & 0.15 & 0.15 & 0.15 \\
Solar & $0.18^{* * *}$ & 0.19 & 0.16 & 0.18 & 0.18 & 0.18 \\
Temp & $0.04^{*}$ & 0.04 & 0.05 & 0.04 & 0.04 & 0.04 \\
DMon & $1.52^{* * *}$ & 1.51 & 1.53 & 1.51 & 1.52 & 1.49 \\
Adj-R & $0.0531^{* * * *}$ & $0.0548^{* * *}$ & $0.0547^{* * *}$ & $0.0535^{* * *}$ & $0.0531^{* * * *}$ & $0.0543^{* * * *}$ \\
\hline
\end{tabular}

〈표 10〉대기오염물질이 개인투자자의 매도비중에 미치는 영향 ***, ** *는 각각 $1 \%, 5 \%, 10 \%$ 수준에서 통계적으로 유의함을 의미함.

\begin{tabular}{lcccccc}
\hline \multicolumn{1}{c}{ TRS,ind } & 1 & 2 & 3 & 4 & 5 & 6 \\
\hline $\mathrm{a}_{0}$ & $47.69^{* * *}$ & $47.68^{* * *}$ & $47.98^{* * *}$ & $47.72^{* * *}$ & $47.70^{* * *}$ & $47.73^{* * *}$ \\
$\mathrm{PM}_{10}$ & 0.01 & & & & \\
$\mathrm{PM}_{2.5}$ & & 0.03 & & & \\
$\mathrm{O}_{3}$ & & 0.04 & & & \\
$\mathrm{NO}_{2}$ & & & -0.01 & & \\
$\mathrm{CO}$ & & & & & \\
$\mathrm{SO}_{2}$ & & & & & \\
$\mathrm{R}_{\mathrm{m}}$ & 0.07 & 0.07 & 0.06 & 0.07 & 0.07 & 0.07 \\
Drain & $2.23^{* * *}$ & $2.28^{* * *}$ & $2.13^{* * *}$ & $2.15^{* * *}$ & $2.18^{* * *}$ & $2.12^{* * *}$ \\
Cloud & $0.19^{*}$ & $0.17^{*}$ & $0.19^{*}$ & $0.20^{*}$ & $0.19^{*}$ & $0.20^{*}$ \\
Solar & $0.12^{* * *}$ & $0.13^{* * *}$ & $0.10^{* * *}$ & $0.12^{* * *}$ & $0.12^{* * *}$ & $0.12^{* * *}$ \\
Temp & 0.02 & 0.02 & 0.03 & 0.02 & 0.02 & 0.02 \\
DMon & $1.53^{* * *}$ & $1.52^{* * *}$ & $1.54^{* * *}$ & $1.53^{* * *}$ & $1.54^{* * * *}$ & $1.52^{* * *}$ \\
Adj-R & $0.0325^{* * * *}$ & $0.0360^{* * *}$ & $0.0339^{* * *}$ & $0.0320^{* * *}$ & $0.0319^{* * *}$ & $0.0321^{* * *}$ \\
\hline
\end{tabular}


한국증권학회지 제49권 3호 (2020)

〈표 11〉대기오염물질이 기관투자자의 매수비중에 미치는 영향

***, ${ }^{* *},{ }^{*}$ 는 각각 $1 \%, 5 \%, 10 \%$ 수준에서 통계적으로 유의함을 의미함.

\begin{tabular}{lcccccc}
\hline \multicolumn{1}{c}{$\mathrm{TR}_{\mathrm{B}, \text { ins }}$} & 1 & 2 & 3 & 4 & 5 & 6 \\
\hline $\mathrm{a}_{0}$ & $22.00^{* * *}$ & $22.01^{* * *}$ & $21.87^{* * *}$ & $22.01^{* * *}$ & $22.02^{* * *}$ & $21.98^{* * *}$ \\
$\mathrm{PM}_{10}$ & -0.01 & & & & \\
$\mathrm{PM}_{2.5}$ & & $-0.02^{* *}$ & & & \\
$\mathrm{O}_{3}$ & & -0.02 & & & \\
$\mathrm{NO}_{2}$ & & & -0.01 & & \\
$\mathrm{CO}$ & & & & -0.01 & \\
$\mathrm{SO}_{2}$ & & & & & 0 \\
$\mathrm{R}_{\mathrm{m}}$ & $-0.14^{* * *}$ & $-0.15^{* * *}$ & $-0.14^{* * *}$ & $-0.14^{* * *}$ & $-0.14^{* * *}$ & $-0.14^{* * *}$ \\
Drain & -0.32 & -0.33 & -0.25 & -0.3 & -0.3 & -0.25 \\
Cloud & 0 & 0 & -0.01 & -0.01 & -0.01 & -0.01 \\
Solar & $-0.09^{* * *}$ & $-0.09^{* * *}$ & $-0.08^{* * *}$ & $-0.09^{* * *}$ & $-0.09^{* * *}$ & $-0.08^{* * *}$ \\
Temp & -0.02 & -0.02 & -0.02 & -0.02 & -0.02 & -0.02 \\
DMon & -0.03 & -0.02 & -0.04 & -0.04 & -0.04 & -0.03 \\
Adj-R & $0.0457^{* * * *}$ & $0.0480^{* * *}$ & $0.0450^{* * *}$ & $0.0443^{* * *}$ & $0.0445^{* * *}$ & $0.0441^{* * *}$ \\
\hline
\end{tabular}

〈표 12〉대기오염물질이 기관투자자의 매도비중에 미치는 영향

***, ${ }^{* *},{ }^{*}$ 는 각각 $1 \%, 5 \%, 10 \%$ 수준에서 통계적으로 유의함을 의미함.

\begin{tabular}{|c|c|c|c|c|c|c|}
\hline $\mathrm{TR}_{\mathrm{S} \text {,ins }}$ & 1 & 2 & 3 & 4 & 5 & 6 \\
\hline$a_{0}$ & $21.09^{* * * * *}$ & $21.09^{* * * *}$ & $20.96^{* * * *}$ & $21.11^{* * * *}$ & $21.07^{* * * *}$ & $21.07^{* * * *}$ \\
\hline $\mathrm{PM}_{10}$ & 0 & & & & & \\
\hline $\mathrm{PM}_{2.5}$ & & 0 & & & & \\
\hline $\mathrm{O}_{3}$ & & & -0.02 & & & \\
\hline $\mathrm{NO}_{2}$ & & & & -0.01 & & \\
\hline $\mathrm{CO}$ & & & & & 0 & \\
\hline $\mathrm{SO}_{2}$ & & & & & & 0.01 \\
\hline $\mathrm{R}_{\mathrm{m}}$ & 0.01 & 0.01 & 0.02 & 0.01 & 0.01 & 0.01 \\
\hline Drain & -0.6 & -0.61 & -0.58 & -0.65 & -0.58 & -0.56 \\
\hline Cloud & -0.06 & -0.06 & -0.06 & -0.06 & -0.07 & -0.07 \\
\hline Solar & -0.01 & -0.01 & 0.01 & -0.01 & 0 & 0 \\
\hline Temp & 0 & 0 & 0 & 0 & 0 & 0 \\
\hline DMon & 0.07 & 0.07 & 0.07 & 0.07 & 0.08 & 0.08 \\
\hline $\operatorname{Adj}-R^{2}$ & -0.0035 & -0.0034 & -0.0021 & -0.0031 & -0.0031 & -0.0031 \\
\hline
\end{tabular}

〈표 13〉대기오염물질이 외국인투자자의 매수비중에 미치는 영향

***, ${ }^{* *},{ }^{*}$ 는 각각 $1 \%, 5 \%, 10 \%$ 수준에서 통계적으로 유의함을 의미함.

\begin{tabular}{lcccccc}
\hline \multicolumn{1}{c}{$\mathrm{TR}_{\mathrm{B}, \text { for }}$} & 1 & 2 & 3 & 4 & 5 & 6 \\
\hline $\mathrm{a}_{0}$ & $31.57^{* * *}$ & $31.59^{* * *}$ & $31.44^{* * *}$ & $31.53^{* * *}$ & $31.54^{* * *}$ & $31.54^{* * * *}$ \\
$\mathrm{PM}_{10}$ & 0.01 & & & & \\
$\mathrm{PM}_{2.5}$ & & 0 & & & \\
$\mathrm{O}_{3}$ & & -0.02 & & & \\
$\mathrm{NO}_{2}$ & & & 0.02 & & \\
$\mathrm{CO}$ & & & & 0.01 & 0.02 \\
$\mathrm{SO}_{2}$ & & & & & \\
\hline
\end{tabular}


Air Pollution, Stock Return, and Volatility

〈표 13〉 대기오염물질이 외국인투자자의 매수비중에 미치는 영향(계속)

\begin{tabular}{lllllll}
\hline \multicolumn{1}{c}{$\mathrm{TR}_{\mathrm{B}, \mathrm{for}}$} & 1 & 2 & 3 & 4 & 5 & 6 \\
\hline $\mathrm{R}_{\mathrm{m}}$ & 0.08 & 0.08 & 0.08 & 0.08 & 0.08 & 0.08 \\
Drain & $-1.87^{* * *}$ & $-1.94^{* * *}$ & $-1.90^{* * *}$ & $-1.83^{* * *}$ & $-1.89^{* * *}$ & $-1.82^{* * * *}$ \\
Cloud & -0.14 & -0.13 & -0.13 & -0.14 & -0.14 & -0.14 \\
Solar & $-0.09^{* *}$ & $-0.10^{* *}$ & $-0.08^{* *}$ & $-0.09^{* *}$ & $-0.09^{* *}$ & $-0.09^{* *}$ \\
Temp & -0.02 & -0.02 & -0.02 & -0.02 & -0.02 & -0.02 \\
DMon & $-1.49^{* * *}$ & $-1.48^{* * *}$ & $-1.49^{* * *}$ & $-1.47^{* * *}$ & $-1.48^{* * *}$ & $-1.46^{* * *}$ \\
Adj-R & $0.0309^{* * *}$ & $0.0301^{* * *}$ & $0.0307^{* * *}$ & $0.0311^{* * *}$ & $0.0304^{* * *}$ & $0.0312^{* * *}$ \\
\hline
\end{tabular}

〈표 14〉대기오염물질이 외국인투자자의 매도비중에 미치는 영향

${ }^{* * *},{ }^{* *},{ }^{*}$ 는 각각 $1 \%, 5 \%, 10 \%$ 수준에서 통계적으로 유의함을 의미함.

\begin{tabular}{|c|c|c|c|c|c|c|}
\hline $\mathrm{TR}_{\mathrm{S}, \text { for }}$ & 1 & 2 & 3 & 4 & 5 & 6 \\
\hline$\overline{a_{0}}$ & $31.73^{* * * *}$ & $31.74^{* * *}$ & $31.62^{* * * *}$ & $31.69^{* * *}$ & $31.75^{* * * *}$ & $31.72^{* * * *}$ \\
\hline $\mathrm{PM}_{10}$ & -0.01 & & & & & \\
\hline $\mathrm{PM}_{2.5}$ & & $-0.03^{* *}$ & & & & \\
\hline $\mathrm{O}_{3}$ & & & -0.01 & & & \\
\hline $\mathrm{NO}_{2}$ & & & & 0.01 & & \\
\hline $\mathrm{CO}$ & & & & & -0.01 & \\
\hline $\mathrm{SO}_{2}$ & & & & & & -0.01 \\
\hline $\mathrm{R}_{\mathrm{m}}$ & -0.06 & -0.06 & -0.05 & -0.05 & -0.05 & -0.05 \\
\hline Drain & $-1.79^{* * * *}$ & $-1.81^{* * * *}$ & $-1.70^{* * * *}$ & $-1.66^{* * *}$ & $-1.74^{* * *}$ & $-1.74^{* * * *}$ \\
\hline Cloud & $-0.16^{*}$ & $-0.15^{*}$ & $-0.17^{*}$ & $-0.18^{* *}$ & $-0.17^{*}$ & $-0.17^{*}$ \\
\hline Solar & $-0.13^{* * * *}$ & $-0.13^{* * *}$ & $-0.12^{* * * *}$ & $-0.12^{* * *}$ & $-0.13^{* * *}$ & $-0.12^{* * * *}$ \\
\hline Temp & -0.01 & -0.01 & -0.02 & -0.02 & -0.01 & -0.02 \\
\hline DMon & $-1.28^{* * * *}$ & $-1.27^{* * * *}$ & $-1.29^{* * * *}$ & $-1.28^{* * *}$ & $-1.30^{* * *}$ & $-1.30^{* * * *}$ \\
\hline $\operatorname{Adj}-R^{2}$ & $0.0331^{* * *}$ & $0.0359^{* * *}$ & $0.0317^{* * *}$ & $0.0317^{* * *}$ & $0.0316^{* * *}$ & $0.0314^{* * *}$ \\
\hline
\end{tabular}

\section{4 대기오염물질과 투자자별 거래비중이 지수수익률 및 변동성에 미치는 영향}

본 절에서는 대기오염물질과 투자자 유형별 거래비중이 지수수익률 및 변동성에 미치는 영향을 알아보고자 한다. 분석에 사용한 회귀분석 식은 <표 $15>$ 와 같으며 분석 결과는 <표 $16>$ <표 18>에서 확인할 수 있다. 이 때 설명변수로 사용된 투자자 유형별 거래비중은 내생성 문제 때문에 전일의 데이터를 사용하여 분석하였다.

$\mathrm{Dep}_{\mathrm{i}, \mathrm{t}}$ 는 수익률 $\left(\mathrm{R}_{\mathrm{t}}\right)$, 역사적변동성 $\left(\mathrm{Vol}_{\mathrm{h}, \mathrm{t}}\right)$, 범위기반변동성 $\left(\mathrm{Vol}_{\mathrm{GK}, \mathrm{t}}\right)$ 등 종속변수를 나타내며, 설명변수로 사용한 변수들은 $\mathrm{AP}_{\mathrm{j}, \mathrm{t}}$ (대기오염물질 변수)와 $\mathrm{TR}_{\mathrm{l}, \mathrm{nt}-1}$ (전일의 투자자 유형별 거래 비중)이고 통제변수로는 $\mathrm{R}_{\mathrm{m}, \mathrm{t}}$ (전월 시장수익률), $\mathrm{W}_{\mathrm{k}, \mathrm{t}}$ (날씨 변수), $\mathrm{DMon}_{\mathrm{t}}($ 요일 더미변수)를 사용하였다. 이 때, $\mathrm{j}$ 는 $\mathrm{PM}_{10}, \mathrm{PM}_{2.5}, \mathrm{O}_{3}, \mathrm{NO}_{2}, \mathrm{SO}_{2}$ 등 6 종류의 대기오염물질을, 1 은 매수(B), 매도(S) 등 거래형태를, $\mathrm{n}$ 은 개인(ind), 기관(ins) 등 투자자 유형을, $\mathrm{k}$ 는 강수(Drain), 구름 양(Cloud), 일사량(Solar), 기온(Temp) 등 날씨를 의미한다. 이 때 회귀분석의 각 설명 변수는 독립이어야 하므로 투자자유형(n) 중 외국인투자자는 제외하고 개인투자자와 기관 
투자자에 대해서만 분석하였다. ${ }^{8)}$ 모형 0은 설명변수에 대기오염물질을 제외한 대조군이며, 모형 1 모형 6은 각 대기오염물질 변수와 각 투자자 유형별 거래비중에 대한 회귀분석 식이다.

〈표 15〉모형의 회귀분석 식

\begin{tabular}{lc}
\hline 모형번호 & 회귀분석 식 \\
\hline 0 & $\mathrm{Dep}_{\mathrm{i}, \mathrm{t}}=\alpha_{0}+\alpha_{1} \mathrm{R}_{\mathrm{m}, \mathrm{t}}+\sum_{\mathrm{t}=1}^{2} \sum_{\mathrm{n}=1}^{2} \beta_{1, \mathrm{n}} \mathrm{TR}_{\mathrm{l}, \mathrm{n}, \mathrm{t}-1}+\sum_{\mathrm{k}=2}^{5} \alpha_{\mathrm{k}} \mathrm{W}_{\mathrm{k}, \mathrm{t}}+\alpha_{6} \mathrm{DMon}_{\mathrm{t}}+\varepsilon_{\mathrm{t}}$ \\
\hline $1 \sim 6$ & $\mathrm{Dep}_{\mathrm{i}, \mathrm{t}}=\alpha_{0}+\alpha_{1} \mathrm{AP}_{\mathrm{j}, \mathrm{t}}+\alpha_{7} \mathrm{R}_{\mathrm{m}, \mathrm{t}}+\sum_{\mathrm{l}=1}^{2} \sum_{\mathrm{n}=1}^{2} \beta_{1, \mathrm{n}} T R_{\mathrm{l}, \mathrm{n}, \mathrm{t}-1}+\sum_{\mathrm{k}=8}^{11} \alpha_{\mathrm{k}} \mathrm{W}_{\mathrm{k}, \mathrm{t}}+\alpha_{12} \mathrm{DMon}_{\mathrm{t}}+\varepsilon_{\mathrm{t}}$ \\
\hline
\end{tabular}

분석 결과, 지수수익률에 영향을 미치는 대기오염물질은 존재하지 않았으나, 초미세먼지와 오존과 이산화질소는 역사적변동성에, 미세먼지와 초미세먼지, 아황산가스는 범위기반변동성에 영향을 미치는 요인으로 나타났다. 즉, 초미세먼지와 오존의 농도가 높아지면 역사적변동성은 감소하고 이산화질소의 농도가 높아질수록 역사적변동성은 증가하였다. 또 미세먼지와 초미세먼지의 농도가 높아질수록 범위기반변동성이 감소하고 아황산가스의 농도가 높아 질수록 범위기반변동성이 증가하는 결과를 보였다.

한편, 지수수익률은 개인의 매도비중과 기관의 매수비중과 음(-)의 상관관계를 나타냈고 지수변동성은 개인투자자와 기관투자자의 매수비중과는 양(+)의 상관관계를, 개인투자자와 기관투자자의 매도비중과는 음(-)의 상관관계를 나타냈다. 즉, 투자자별로 대기오염에 대한 반응이 상이함을 의미하며 이는 투자자별 거래량이 주가변동성에 미치는 영향이 다르다고 주장한 $\mathrm{YoO}(2014)$ 의 연구결과와 일치한다.

〈표 16〉대기오염물질과 투자자별 거래비중이 수익률에 미치는 영향 ***, ${ }^{* *},{ }^{*}$ 는 각각 $1 \%, 5 \%, 10 \%$ 수준에서 통계적으로 유의함을 의미함.

\begin{tabular}{lccccccc}
\hline \multicolumn{1}{c}{$\mathrm{R}_{\mathrm{t}}$} & 0 & 1 & 2 & 3 & 4 & 5 & 6 \\
\hline $\mathrm{a}_{0}$ & $1.21^{* * *}$ & $1.23^{* * *}$ & $1.23^{* * *}$ & $1.22^{* * *}$ & $1.22^{* * *}$ & $1.21^{* * *}$ & $1.22^{* * *}$ \\
$\mathrm{PM}_{10}$ & & 0 & & & & & \\
$\mathrm{PM}_{2.5}$ & & & 0 & & & & \\
$\mathrm{O}_{3}$ & & & & & & \\
$\mathrm{NO}_{2}$ & & & & & & 0 & \\
$\mathrm{CO}$ & & & & & & & 0 \\
$\mathrm{SO}_{2}$ & 0 & 0 & 0 & 0 & 0 & 0 & 0 \\
$\mathrm{TR}_{\mathrm{B}, \text { ind }}$ & $-0.02^{*}$ & $-0.02^{*}$ & $-0.02^{*}$ & $-0.02^{*}$ & $-0.02^{*}$ & $-0.02^{*}$ & $-0.02^{*}$ \\
$\mathrm{TR}_{\mathrm{S} \text {,ind }}$ & $-0.02^{* *}$ & $-0.02^{* *}$ & $-0.02^{* *}$ & $-0.02^{* *}$ & $-0.02^{* *}$ & $-0.02^{* *}$ & $-0.02^{* *}$ \\
$\mathrm{TR}_{\mathrm{B}, \text { ins }}$ & & & & & & & \\
\hline
\end{tabular}

8) 회귀분석의 사전작업으로 모든 투자자 유형의 경우의 수(개인과 기관, 개인과 외국인, 기관과 외국인)에 대하여 분석하였고, 그 결과 개인과 기관 유형에 대하여 분석하는 편이 다른 두 경우 보다 결정계수 $\left(\operatorname{adj}-R^{2}\right)$ 가 높으므로 설명변수로 채택하였다. 
Air Pollution, Stock Return, and Volatility

〈표 16〉대기오염물질과 투자자별 거래비중이 수익률에 미치는 영향(계속)

\begin{tabular}{lrrrrrrr}
\hline \multicolumn{1}{c}{$\mathrm{R}_{\mathrm{t}}$} & \multicolumn{1}{c}{1} & \multicolumn{1}{c}{2} & \multicolumn{2}{c}{3} & 4 & \multicolumn{1}{c}{5} & \multicolumn{1}{c}{6} \\
\hline $\mathrm{TR}_{\mathrm{S}, \text { ins }}$ & 0 & 0 & 0 & 0 & 0 & 0 & 0 \\
$\mathrm{R}_{\mathrm{m}}$ & 0 & 0 & 0 & 0 & 0 & 0 & 0 \\
Drain & -0.09 & -0.08 & -0.08 & -0.09 & -0.1 & -0.09 & -0.08 \\
Cloud & 0 & 0 & 0 & 0 & 0 & 0 & 0 \\
Solar & 0 & 0 & 0 & 0 & 0 & 0 & 0 \\
Temp & 0 & 0 & 0 & 0 & 0 & 0 & 0 \\
DMon & $-0.11^{*}$ & $-0.11^{*}$ & $-0.11^{*}$ & $-0.11^{*}$ & $-0.11^{*}$ & $-0.11^{*}$ & $-0.11^{*}$ \\
Adj-R & $0.0124^{* *}$ & $0.0131^{* *}$ & $0.0127^{* *}$ & $0.0117^{* *}$ & $0.0119^{* *}$ & $0.0114^{* *}$ & $0.0117^{* *}$ \\
\hline
\end{tabular}

〈표 17〉 대기오염물질과 투자자별 거래비중이 역사적변동성에 미치는 영향 ***, ${ }^{* *}$,는 각각 $1 \%, 5 \%, 10 \%$ 수준에서 통계적으로 유의함을 의미함.

\begin{tabular}{|c|c|c|c|c|c|c|c|}
\hline $\mathrm{Vol}_{\mathrm{h}, \mathrm{t}}$ & 0 & 1 & 2 & 3 & 4 & 5 & 6 \\
\hline$\overline{a_{0}}$ & $10.64^{* * * *}$ & $10.60^{* * * *}$ & $10.51^{* * *}$ & $10.52^{* * *}$ & $10.54^{* * *}$ & $10.64^{* * *}$ & $10.67^{* * *}$ \\
\hline $\mathrm{PM}_{10}$ & & -0.01 & & & & & \\
\hline $\mathrm{PM}_{2.5}$ & & & $-0.02^{* *}$ & & & & \\
\hline $\mathrm{O}_{3}$ & & & & $-0.03^{*}$ & & & \\
\hline $\mathrm{NO}_{2}$ & & & & & $0.02^{*}$ & & \\
\hline $\mathrm{CO}$ & & & & & & 0 & \\
\hline $\mathrm{SO}_{2}$ & & & & & & & 0.01 \\
\hline $\mathrm{TR}_{\mathrm{B}, \text { ind }}$ & $0.11^{* * * *}$ & $0.11^{* * *}$ & $0.11^{* * * *}$ & $0.11^{* * *}$ & $0.11^{* * * *}$ & $0.11^{* * *}$ & $0.11^{* * * *}$ \\
\hline $\mathrm{TR}_{\mathrm{S} \text {, ind }}$ & $-0.08^{* *}$ & $-0.07^{* *}$ & $-0.07^{* *}$ & $-0.08^{* *}$ & $-0.08^{* *}$ & $-0.08^{* *}$ & $-0.08^{* *}$ \\
\hline $\mathrm{TR}_{\mathrm{B} \text {,ins }}$ & $0.10^{* * * *}$ & $0.10^{* * *}$ & $0.10^{* * * *}$ & $0.10^{* * * *}$ & $0.10^{* * * *}$ & $0.10^{* * * *}$ & $0.10^{* * * *}$ \\
\hline $\mathrm{TR}_{\mathrm{S} \text {,ins }}$ & $-0.10^{* * * *}$ & $-0.10^{* * * *}$ & $-0.10^{* * * *}$ & $-0.10^{* * * *}$ & $-0.10^{* * * *}$ & $-0.10^{* * * *}$ & $-0.10^{* * *}$ \\
\hline $\mathrm{R}_{\mathrm{m}}$ & $-0.64^{* * * *}$ & $-0.64^{* * *}$ & $-0.65^{* * * *}$ & $-0.64^{* * * *}$ & $-0.64^{* * * *}$ & $-0.64^{* * *}$ & $-0.64^{* * * *}$ \\
\hline Drain & -0.27 & -0.31 & -0.32 & -0.24 & -0.18 & -0.27 & -0.21 \\
\hline Cloud & 0.04 & 0.04 & 0.05 & 0.04 & 0.03 & 0.04 & 0.04 \\
\hline Solar & -0.03 & -0.03 & -0.03 & -0.01 & -0.02 & -0.03 & -0.02 \\
\hline Temp & $-0.03^{* *}$ & $-0.03^{* *}$ & $-0.03^{* *}$ & $-0.03^{* *}$ & $-0.03^{* *}$ & $-0.03^{* *}$ & $-0.03^{* *}$ \\
\hline DMon & 0.14 & 0.15 & 0.15 & 0.13 & 0.16 & 0.14 & 0.15 \\
\hline $\operatorname{Adj}-R^{2}$ & $0.3548^{* * *}$ & $0.3552^{* * *}$ & $0.3568^{* * *}$ & $0.3563^{* * * *}$ & $0.3561^{* * *}$ & $0.3541^{* * *}$ & $0.3548^{* * * *}$ \\
\hline
\end{tabular}

〈표 18〉 대기오염물질과 투자자별 거래비중이 범위기반변동성에 미치는 영향 ${ }^{* * *},{ }^{* *},{ }^{*}$ 는 각각 $1 \%, 5 \%, 10 \%$ 수준에서 통계적으로 유의함을 의미함.

\begin{tabular}{|c|c|c|c|c|c|c|c|}
\hline Vol $_{\mathrm{GK}, \mathrm{t}}$ & 0 & 1 & 2 & 3 & 4 & 5 & 6 \\
\hline$\overline{a_{0}}$ & $8.46^{* * * *}$ & $8.42^{* * * *}$ & $8.35^{* * *}$ & $8.42^{* * *}$ & $8.45^{* * *}$ & $8.49^{* * * *}$ & $8.49^{* * * *}$ \\
\hline $\mathrm{PM}_{10}$ & & $-0.01^{*}$ & & & & & \\
\hline $\mathrm{PM}_{2.5}$ & & & $-0.01^{* * *}$ & & & & \\
\hline $\mathrm{O}_{3}$ & & & & -0.01 & & & \\
\hline $\mathrm{NO}_{2}$ & & & & & 0 & & \\
\hline $\mathrm{CO}$ & & & & & & -0.01 & \\
\hline $\mathrm{SO}_{2}$ & & & & & & & $0.01^{*}$ \\
\hline $\mathrm{TR}_{\mathrm{B} \text {,ind }}$ & $0.07^{* * * *}$ & $0.06^{* * *}$ & $0.06^{* * *}$ & $0.07^{* * *}$ & $0.07^{* * *}$ & $0.07^{* * *}$ & $0.07^{* * *}$ \\
\hline $\mathrm{TR}_{\mathrm{S} \text {,ind }}$ & $-0.05^{* *}$ & $-0.05^{* *}$ & $-0.05^{* *}$ & $-0.05^{* *}$ & $-0.05^{* *}$ & $-0.05^{* *}$ & $-0.05^{* *}$ \\
\hline $\mathrm{TR}_{\mathrm{B}, \text { ins }}$ & $0.08^{* * *}$ & $0.07^{* * *}$ & $0.07^{* * *}$ & $0.08^{* * *}$ & $0.08^{* * * *}$ & $0.08^{* * * *}$ & $0.08^{* * * *}$ \\
\hline
\end{tabular}


한국증권학회지 제49권 3호 (2020)

〈표 18〉대기오염물질과 투자자별 거래비중이 범위기반변동성에 미치는 영향(계속)

\begin{tabular}{|c|c|c|c|c|c|c|c|}
\hline $\mathrm{Vol}_{\mathrm{GK}, \mathrm{t}}$ & 0 & 1 & 2 & 3 & 4 & 5 & 6 \\
\hline$\overline{\mathrm{TR}_{\mathrm{S} \text {,ins }}}$ & $-0.09^{* * * *}$ & $-0.09^{* * *}$ & $-0.09^{* * *}$ & $-0.09^{* * *}$ & $-0.09^{* * *}$ & $-0.09^{* * *}$ & $-0.09^{* * *}$ \\
\hline $\mathrm{R}_{\mathrm{m}}$ & $-0.42^{* * *}$ & $-0.42^{* * *}$ & $-0.42^{* * *}$ & $-0.41^{* * *}$ & $-0.41^{* * *}$ & $-0.42^{* * *}$ & $-0.41^{* * *}$ \\
\hline Drain & -0.24 & -0.28 & -0.28 & -0.22 & -0.22 & -0.27 & -0.17 \\
\hline Cloud & 0.02 & 0.02 & 0.03 & 0.02 & 0.02 & 0.02 & 0.01 \\
\hline Solar & 0 & -0.01 & -0.01 & 0 & 0 & -0.01 & 0 \\
\hline Temp & $0.02^{* * *}$ & $0.02^{* * *}$ & $0.02^{* * *}$ & $0.02^{* *}$ & $0.02^{* *}$ & $0.02^{* *}$ & $0.02^{* *}$ \\
\hline DMon & 0.03 & 0.03 & 0.03 & 0.02 & 0.03 & 0.02 & 0.04 \\
\hline $\mathrm{Adj}-\mathrm{R}^{2}$ & $0.3498^{* * * *}$ & $0.3512^{* * *}$ & $0.3539^{* * *}$ & $0.3497^{* * *}$ & $0.3493^{* * *}$ & $0.3505^{* * *}$ & $0.3510^{* * * *}$ \\
\hline
\end{tabular}

\section{5 대기오염물질의 장기간노출이 주식시장에 미치는 영향}

제 2.2절에서 제시한 의학 문헌을 토대로 대기오염물질에 노출되면 건강 악화 등의 문제가 발생하며 특히 대기오염물질의 장기간 노출시에 그 영향력이 증가함을 알 수 있다. Schwarz(2000)는 대기 오염이 사망에 미치는 영향을 검토한 결과, 대기오염의 3 일간 이동평균이 사망에 미치는 영향이 대기오염의 일 평균이 사망에 미치는 영향에 비해 더 큰 것으로 나타났다. 이를 통해 장기간 노출된 대기오염물질이 주식시장에 미치는 영향력 역시 증가할 것으로 추론 할 수 있다.

본 절에서는 대기오염물질의 장기간노출이 주식시장에 미치는 영향을 알아보고 특히, 노출 기간에 따른 영향력을 분석하기 위하여 3일, 5일, 7일 평균을 식 (7) 식 (9)와 같이 정의한 후에 대기오염물질 $\left(\mathrm{AP}_{\mathrm{j}, \mathrm{t}}\right)$ 을 대기오염물질의 $p$ 일 이동평균 $\left(m e a n p A \mathrm{P}_{\mathrm{j}, \mathrm{t}}, p=3,5,7\right)$ 로 대체하고 모형을 다시 추정한다. 분석 결과는 <표 19> <표 21>에서 확인할 수 있다.

$$
\begin{aligned}
& \operatorname{mean} 3 \mathrm{AP}_{\mathrm{j}, \mathrm{t}}=\frac{1}{3} \sum_{p=1}^{3} \mathrm{AP}_{\mathrm{j}, \mathrm{t}-p+1} \\
& \operatorname{mean} 5 \mathrm{AP}_{\mathrm{j}, \mathrm{t}}=\frac{1}{5} \sum_{p=1}^{5} \mathrm{AP}_{\mathrm{j}, \mathrm{t}-p+1} \\
& \operatorname{mean} 7 \mathrm{AP}_{\mathrm{j}, \mathrm{t}}=\frac{1}{7} \sum_{p=1}^{7} \mathrm{AP}_{\mathrm{j}, \mathrm{t}-p+1}
\end{aligned}
$$

제 5.2절에서 지수수익률에 영향을 미치는 대기오염물질은 존재하지 않았으나, 일산화 탄소의 5일 이동평균은 지수수익률에 영향을 미치는 것으로 나타났다(모형 19 참조).

또한 대기오염물질의 노출기간이 길수록 지수변동성에 더 많은 영향력을 행사하는 것을 알 수 있었다. 미세먼지와 초미세먼지와 오존의 농도가 높을수록 역사적변동성은 감소하였고 이산화질소의 농도가 높을수록 역사적변동성은 증가하였다. 또 미세먼지와 초미세먼지, 오존, 이산화질소에 지속적으로 노출될수록 역사적변동성의 변동폭은 증가하였으며 특히 미세먼지와 오존과 이산화질소의 당일 노출시에는 역사적변동성이 변화하지 않았으나, 3 일 이상 지속적으로 노출시에 역사적변동성에 영향을 미치는 것을 알 수 있었다. 
Air Pollution, Stock Return, and Volatility

범위기반변동성의 경우에도 유사한 결과가 나타났다. 미세먼지와 초미세먼지와 일산화 탄소의 농도가 높을수록 범위기반변동성은 감소하였고 이산화질소, 아황산가스의 농도가 높을수록 범위기반변동성은 증가하였다. 또 초미세먼지와 이산화질소, 아황산가스에 장기간 지속적으로 노출될수록 범위기반변동성의 변동폭은 증가하였다. 특히, 이산화질소와 아황산 가스에 당일노출시 범위기반변동성이 변화하지 않았으나 이산화질소에 7 일 이상 노출시와 아황산가스에 3 일 이상 노출시에 범위기반변동성이 증가하였다. 한편, 미세먼지의 경우에는 당일노출과 3 일 노출시에는 범위기반변동성이 감소하였으나 5 일 이상 노출시에 범위기반 변동성에 유의한 변화가 없었다. 즉, 대기오염물질의 일 평균보다 누적 평균이 지수수익률 및 변동성에 미치는 영향이 큰 것을 확인할 수 있었다.

〈표 19〉대기오염물질의 장기간노출이 수익률에 미치는 영향 ***, ** *는 각각 $1 \%, 5 \%, 10 \%$ 수준에서 통계적으로 유의함을 의미함.

\begin{tabular}{|c|c|c|c|c|c|c|c|c|}
\hline $\mathrm{R}_{\mathrm{t}}$ & 1 & 2 & 3 & 4 & 5 & 6 & 7 & 8 \\
\hline$\overline{a_{0}}$ & 0.09 & 0.09 & 0.1 & 0.1 & 0.09 & 0.1 & 0.1 & 0.1 \\
\hline $\mathrm{PM}_{10}$ & 0 & & & & & & & \\
\hline mean $3 \mathrm{PM}_{10}$ & & 0 & & & & & & \\
\hline mean5 $\mathrm{PM}_{10}$ & & & 0 & & & & & \\
\hline mean7PM 10 & & & & 0 & & & & \\
\hline $\mathrm{PM}_{2.5}$ & & & & & 0 & & & \\
\hline mean $3 \mathrm{PM}_{2.5}$ & & & & & & 0 & & \\
\hline mean5 $\mathrm{PM}_{2.5}$ & & & & & & & $-0.01^{*}$ & \\
\hline mean7PM 2.5 & & & & & & & & 0 \\
\hline $\mathrm{R}_{\mathrm{m}}$ & 0 & 0 & 0 & 0 & 0 & 0 & 0 & 0 \\
\hline Drain & -0.1 & -0.12 & -0.12 & -0.12 & -0.11 & -0.12 & -0.12 & -0.12 \\
\hline Cloud & -0.01 & 0 & 0 & 0 & -0.01 & 0 & 0 & 0 \\
\hline Solar & 0 & 0 & 0 & 0 & 0 & 0 & 0 & 0 \\
\hline Temp & 0 & 0 & 0 & 0 & 0 & 0 & 0 & 0 \\
\hline DMon & -0.09 & -0.09 & -0.09 & -0.09 & -0.09 & -0.09 & -0.09 & -0.09 \\
\hline $\operatorname{Adj}-R^{2}$ & -0.0007 & -0.0021 & -0.0008 & -0.0018 & -0.0012 & -0.0019 & 0.0014 & -0.0008 \\
\hline $\mathrm{R}_{\mathrm{t}}$ & 9 & 10 & 11 & 12 & 13 & 14 & 15 & 16 \\
\hline$\overline{a_{0}}$ & 0.11 & 0.11 & 0.11 & 0.1 & 0.1 & 0.1 & 0.11 & 0.1 \\
\hline $\mathrm{O}_{3}$ & 0 & & & & & & & \\
\hline mean $3 \mathrm{O}_{3}$ & & 0 & & & & & & \\
\hline mean $5 \mathrm{O}_{3}$ & & & 0 & & & & & \\
\hline mean $7 \mathrm{O}_{3}$ & & & & 0 & & & & \\
\hline $\mathrm{NO}_{2}$ & & & & & 0 & & & \\
\hline mean $3 \mathrm{NO}_{2}$ & & & & & & 0 & & \\
\hline mean $5 \mathrm{NO}_{2}$ & & & & & & & $-0.01^{* * *}$ & \\
\hline mean7 $\mathrm{NO}_{2}$ & & & & & & & & -0.01 \\
\hline $\mathrm{R}_{\mathrm{m}}$ & 0 & 0 & 0 & 0 & 0 & 0 & 0 & 0 \\
\hline Drain & -0.12 & -0.12 & -0.12 & -0.12 & -0.12 & -0.12 & -0.12 & -0.12 \\
\hline Cloud & 0 & 0 & 0 & 0 & 0 & 0 & 0 & 0 \\
\hline Solar & 0 & 0 & 0 & 0 & 0 & 0 & 0 & 0 \\
\hline Temp & 0 & 0 & 0 & 0 & 0 & 0 & 0 & 0 \\
\hline DMon & -0.09 & -0.09 & -0.09 & -0.09 & -0.09 & -0.09 & -0.09 & -0.09 \\
\hline $\operatorname{Adj}-R^{2}$ & -0.0019 & -0.0018 & -0.0018 & -0.0021 & -0.0018 & -0.0002 & 0.0047 & 0.0005 \\
\hline
\end{tabular}


한국증권학회지 제49권 3호 (2020)

〈표 19〉 대기오염물질의 장기간노출이 수익률에 미치는 영향(계속)

\begin{tabular}{|c|c|c|c|c|c|c|c|c|}
\hline $\mathrm{R}_{\mathrm{t}}$ & 17 & 18 & 19 & 20 & 21 & 22 & 23 & 24 \\
\hline$\overline{a_{0}}$ & 0.09 & 0.1 & 0.12 & 0.11 & 0.09 & 0.1 & 0.1 & 0.1 \\
\hline $\mathrm{CO}$ & 0 & & & & & & & \\
\hline mean3CO & & 0 & & & & & & \\
\hline mean5CO & & & $-0.01^{\text {****** }}$ & & & & & \\
\hline mean7CO & & & & $-0.01^{*}$ & & & & \\
\hline $\mathrm{SO}_{2}$ & & & & & 0 & & & \\
\hline mean $3 \mathrm{SO}_{2}$ & & & & & & 0 & & \\
\hline mean $5 \mathrm{SO}_{2}$ & & & & & & & -0.01 & \\
\hline mean $7 \mathrm{SO}_{2}$ & & & & & & & & 0 \\
\hline $\mathrm{R}_{\mathrm{m}}$ & 0 & 0 & 0 & 0 & 0 & 0 & 0 & 0 \\
\hline Drain & -0.12 & -0.12 & -0.12 & -0.12 & -0.11 & -0.12 & -0.12 & -0.12 \\
\hline Cloud & 0 & 0 & 0 & 0 & 0 & 0 & 0 & 0 \\
\hline Solar & 0 & 0 & 0 & 0 & 0 & 0 & 0 & 0 \\
\hline Temp & 0 & 0 & 0 & 0 & 0 & 0 & 0 & 0 \\
\hline DMon & -0.09 & -0.09 & -0.09 & -0.09 & -0.09 & -0.09 & -0.09 & -0.09 \\
\hline Adj- $R^{2}$ & -0.0021 & -0.0003 & $0.0054^{*}$ & 0.0007 & -0.0019 & -0.0019 & -0.0007 & -0.0016 \\
\hline
\end{tabular}

〈표 20〉대기오염물질의 장기간노출이 역사적변동성에 미치는 영향 ***, **는 각각 $1 \%, 5 \%, 10 \%$ 수준에서 통계적으로 유의함을 의미함.

\begin{tabular}{|c|c|c|c|c|c|c|c|c|}
\hline $\mathrm{Vol}_{\mathrm{h}, \mathrm{t}}$ & 1 & 2 & 3 & 4 & 5 & 6 & 7 & 8 \\
\hline$\overline{a_{0}}$ & $12.41^{* * * *}$ & $12.42^{* * * *}$ & $12.42^{* * * *}$ & $12.44^{* * * *}$ & $12.41^{* * * *}$ & $12.44^{* * * *}$ & $12.46^{* * * *}$ & $12.48^{* * * *}$ \\
\hline $\mathrm{PM}_{10}$ & -0.01 & & & & & & & \\
\hline mean $3 \mathrm{PM}_{10}$ & & $-0.01^{* *}$ & & & & & & \\
\hline mean5 $\mathrm{PM}_{10}$ & & & $-0.02^{*}$ & & & & & \\
\hline mean7PM 10 & & & & $-0.02^{* *}$ & & & & \\
\hline $\mathrm{PM}_{2.5}$ & & & & & $-0.02^{* *}$ & & & \\
\hline mean3PM 2.5 & & & & & & $-0.03^{* * * *}$ & & \\
\hline mean5 $\mathrm{PM}_{2.5}$ & & & & & & & $-0.04^{* * * *}$ & \\
\hline mean7PM ${ }_{2.5}$ & & & & & & & & $-0.06^{* * *}$ \\
\hline $\mathrm{R}_{\mathrm{m}}$ & $-0.66^{* * * *}$ & $-0.66^{* * *}$ & $-0.66^{* * * *}$ & $-0.66^{* * *}$ & $-0.66^{* * * *}$ & $-0.66^{* * * *}$ & $-0.67^{* * * *}$ & $-0.67^{* * * *}$ \\
\hline Drain & -0.26 & -0.23 & -0.22 & -0.22 & -0.26 & -0.25 & -0.23 & -0.24 \\
\hline Cloud & 0.06 & 0.06 & 0.05 & 0.05 & 0.06 & 0.06 & 0.05 & 0.05 \\
\hline Solar & -0.03 & -0.03 & -0.03 & -0.03 & -0.03 & -0.03 & -0.03 & -0.03 \\
\hline Solar & -0.03 & -0.03 & -0.03 & -0.03 & -0.03 & -0.03 & -0.03 & -0.03 \\
\hline Temp & $-0.03^{* *}$ & $-0.03^{* *}$ & $-0.03^{* *}$ & $-0.03^{* *}$ & $-0.03^{* *}$ & $-0.03^{* *}$ & $-0.03^{* *}$ & $-0.03^{* *}$ \\
\hline DMon & 0.12 & 0.12 & 0.12 & 0.12 & 0.13 & 0.12 & 0.11 & 0.12 \\
\hline $\operatorname{Adj}-R^{2}$ & $0.3443^{* * * *}$ & $0.3453^{* * * *}$ & $0.3450^{* * * *}$ & $0.3463^{* * *}$ & $0.3458^{* * * *}$ & $0.3482^{* * * *}$ & $0.3507^{* * * *}$ & $0.3542^{* * * *}$ \\
\hline $\mathrm{Vol}_{\mathrm{h}, \mathrm{t}}$ & 9 & 10 & 11 & 12 & 13 & 14 & 15 & 16 \\
\hline$a_{0}$ & $12.24^{* * * *}$ & $12.20^{* * * *}$ & $12.21^{* * * *}$ & $12.24^{* * * *}$ & $12.35^{* * * *}$ & $12.36^{* * * *}$ & $12.35^{* * * *}$ & $12.35^{* * * *}$ \\
\hline $\mathrm{O}_{3}$ & -0.02 & & & & & & & \\
\hline mean $3 \mathrm{O}_{3}$ & & $-0.04^{* *}$ & & & & & & \\
\hline mean $5 \mathrm{O}_{3}$ & & & $-0.04^{* *}$ & & & & & \\
\hline mean $7 \mathrm{O}_{3}$ & & & & $-0.04^{*}$ & & & & \\
\hline $\mathrm{NO}_{2}$ & & & & & 0.02 & & & \\
\hline mean $3 \mathrm{NO}_{2}$ & & & & & & $0.03^{* *}$ & & \\
\hline mean $5 \mathrm{NO}_{2}$ & & & & & & & $0.04^{* *}$ & \\
\hline
\end{tabular}


Air Pollution, Stock Return, and Volatility

〈표 20〉 대기오염물질의 장기간노출이 역사적변동성에 미치는 영향(계속)

\begin{tabular}{|c|c|c|c|c|c|c|c|c|}
\hline $\mathrm{Vol}_{\mathrm{h}, \mathrm{t}}$ & 9 & 10 & 11 & 12 & 13 & 14 & 15 & 16 \\
\hline mean7 $\mathrm{NO}_{2}$ & & & & & & & & $0.04^{* *}$ \\
\hline $\mathrm{R}_{\mathrm{m}}$ & $-0.65^{* * *}$ & $-0.65^{* * *}$ & $-0.65^{* * *}$ & $-0.65^{* * * *}$ & $-0.65^{* * *}$ & $-0.65^{* * * *}$ & $-0.65^{* * * *}$ & $-0.65^{* * * *}$ \\
\hline Drain & -0.18 & -0.18 & -0.17 & -0.17 & -0.12 & -0.16 & -0.18 & -0.17 \\
\hline Cloud & 0.05 & 0.05 & 0.05 & 0.05 & 0.04 & 0.04 & 0.04 & 0.05 \\
\hline Solar & -0.01 & -0.01 & -0.01 & -0.02 & -0.02 & -0.02 & -0.02 & -0.02 \\
\hline Temp & $-0.03^{* *}$ & $-0.03^{* *}$ & $-0.03^{* *}$ & $-0.03^{* * *}$ & $-0.03^{* *}$ & $-0.03^{* *}$ & $-0.03^{* *}$ & $-0.03^{* *}$ \\
\hline DMon & 0.11 & 0.12 & 0.12 & 0.12 & 0.13 & 0.11 & 0.12 & 0.12 \\
\hline Adj-R ${ }^{2}$ & $0.3444^{* * * *}$ & $0.3463^{* * * *}$ & $0.3460^{* * * *}$ & $0.3448^{* * *}$ & $0.3441^{* * * *}$ & $0.3455^{* * * *}$ & $0.3460^{* * * *}$ & $0.3455^{* * * *}$ \\
\hline $\mathrm{Vol}_{\mathrm{h}, \mathrm{t}}$ & 17 & 18 & 19 & 20 & 21 & 22 & 23 & 24 \\
\hline$\overline{a_{0}}$ & 12.4 & 12.41 & 12.42 & 12.44 & 12.38 & 12.37 & 12.37 & 12.38 \\
\hline $\mathrm{CO}$ & 0 & & & & & & & \\
\hline mean $3 \mathrm{CO}$ & & 0 & & & & & & \\
\hline mean $5 \mathrm{CO}$ & & & -0.01 & & & & & \\
\hline mean7CO & & & & -0.01 & & & & \\
\hline $\mathrm{SO}_{2}$ & & & & & 0.01 & & & \\
\hline mean $3 \mathrm{SO}_{2}$ & & & & & & 0.02 & & \\
\hline mean $5 \mathrm{SO}_{2}$ & & & & & & & 0.02 & \\
\hline mean $7 \mathrm{SO}_{2}$ & & & & & & & & 0.02 \\
\hline $\mathrm{R}_{\mathrm{m}}$ & $-0.66^{* * * *}$ & $-0.66^{* * * *}$ & $-0.66^{* * * *}$ & $-0.66^{* * *}$ & $-0.65^{* * *}$ & $-0.65^{* * * *}$ & $-0.65^{* * * *}$ & $-0.65^{* * * *}$ \\
\hline Drain & -0.21 & -0.21 & -0.21 & -0.22 & -0.16 & -0.17 & -0.18 & -0.18 \\
\hline Cloud & 0.05 & 0.05 & 0.05 & 0.05 & 0.05 & 0.05 & 0.05 & 0.05 \\
\hline Solar & -0.02 & -0.03 & -0.03 & -0.03 & -0.02 & -0.02 & -0.02 & -0.02 \\
\hline Temp & $-0.03^{* *}$ & $-0.03^{* *}$ & $-0.03^{* *}$ & $-0.03^{* * *}$ & $-0.03^{* *}$ & $-0.03^{* *}$ & $-0.03^{* *}$ & $-0.03^{* *}$ \\
\hline DMon & 0.12 & 0.12 & 0.11 & 0.11 & 0.13 & 0.12 & 0.12 & 0.12 \\
\hline Adj-R ${ }^{2}$ & $0.3426^{* * *}$ & $0.3426^{\text {**** }}$ & $0.3428^{* * * *}$ & $0.3433^{* * *}$ & $0.3430^{* * *}$ & $0.3432^{* * * *}$ & $0.3434^{\text {**** }}$ & $0.3432^{* * * *}$ \\
\hline
\end{tabular}

〈표 21〉 대기오염물질의 장기간노출이 범위기반변동성에 미치는 영향 ${ }^{* * *},{ }^{* *},{ }^{*}$ 는 각각 $1 \%, 5 \%, 10 \%$ 수준에서 통계적으로 유의함을 의미함.

\begin{tabular}{|c|c|c|c|c|c|c|c|c|}
\hline $\mathrm{Vol}_{\mathrm{GK}, \mathrm{t}}$ & 1 & 2 & 3 & 4 & 5 & 6 & 7 & 8 \\
\hline$a_{0}$ & $8.92^{* * * *}$ & $8.93^{* * * *}$ & $8.93^{* * * *}$ & $8.93^{* * * *}$ & $8.93^{* * * *}$ & $8.94^{* * * *}$ & $8.95^{* * *}$ & $8.96^{* * * *}$ \\
\hline $\mathrm{PM}_{10}$ & $-0.01^{\text {** }}$ & & & & & & & \\
\hline mean $3 \mathrm{PM}_{10}$ & & $-0.01^{* *}$ & & & & & & \\
\hline mean $5 \mathrm{PM}_{10}$ & & & -0.01 & & & & & \\
\hline mean7PM 10 & & & & -0.01 & & & & \\
\hline $\mathrm{PM}_{2.5}$ & & & & & $-0.02^{* * *}$ & & & \\
\hline mean $3 \mathrm{PM}_{2.5}$ & & & & & & $-0.02^{* * * * *}$ & & \\
\hline mean5PM 2.5 & & & & & & & $-0.03^{* * * *}$ & \\
\hline mean $7 \mathrm{PM}_{2.5}$ & & & & & & & & $-0.04^{* * * *}$ \\
\hline $\mathrm{R}_{\mathrm{m}}$ & $-0.43^{* * * *}$ & $-0.43^{* * * *}$ & $-0.43^{* * * *}$ & $-0.43^{* * *}$ & $-0.43^{* * * *}$ & $-0.43^{* * * *}$ & $-0.43^{* * * *}$ & $-0.43^{* * * *}$ \\
\hline Drain & -0.25 & -0.22 & -0.21 & -0.21 & -0.25 & -0.23 & -0.22 & -0.22 \\
\hline Cloud & 0.03 & 0.03 & 0.02 & 0.02 & 0.03 & 0.03 & 0.02 & 0.02 \\
\hline Solar & -0.01 & -0.01 & -0.01 & -0.01 & -0.01 & -0.01 & -0.01 & -0.01 \\
\hline Temp & $0.02^{* *}$ & $0.02^{* *}$ & $0.02^{* *}$ & $0.02^{* *}$ & $0.02^{* *}$ & $0.02^{* *}$ & $0.02^{* *}$ & $0.02^{* *}$ \\
\hline DMon & 0.03 & 0.02 & 0.02 & 0.02 & 0.03 & 0.02 & 0.02 & 0.02 \\
\hline $\operatorname{Adj}-R^{2}$ & $0.3379^{* * * *}$ & $0.3379^{* * * *}$ & $0.3365^{\text {**** }}$ & $0.3357^{* * * *}$ & $0.3405^{* * * *}$ & $0.3424^{* * * *}$ & $0.3435^{* * *}$ & $0.3437^{* * * *}$ \\
\hline
\end{tabular}


한국증권학회지 제49권 3호 (2020)

〈표 21〉 대기오염물질의 장기간노출이 범위기반변동성에 미치는 영향(계속)

\begin{tabular}{|c|c|c|c|c|c|c|c|c|}
\hline Vol $_{\mathrm{GK}, \mathrm{t}}$ & 9 & 10 & 11 & 12 & 13 & 14 & 15 & 16 \\
\hline$\overline{a_{0}}$ & $8.87^{* * * *}$ & $8.87^{* * * *}$ & $8.87^{* * * *}$ & $8.87^{* * * * *}$ & $8.91^{* * * *}$ & $8.90^{* * * * *}$ & $8.89^{* * * * *}$ & $8.88^{* * * * *}$ \\
\hline $\mathrm{O}_{3}$ & -0.01 & & & & & & & \\
\hline mean $3 \mathrm{O}_{3}$ & & -0.01 & & & & & & \\
\hline mean $5 \mathrm{O}_{3}$ & & & -0.01 & & & & & \\
\hline mean $7 \mathrm{O}_{3}$ & & & & -0.01 & & & & \\
\hline $\mathrm{NO}_{2}$ & & & & & 0 & & & \\
\hline mean $3 \mathrm{NO}_{2}$ & & & & & & 0.01 & & \\
\hline mean $5 \mathrm{NO}_{2}$ & & & & & & & 0.02 & \\
\hline mean $7 \mathrm{NO}_{2}$ & & & & & & & & $0.03^{* *}$ \\
\hline $\mathrm{R}_{\mathrm{m}}$ & $-0.42^{* * * *}$ & $-0.42^{* * * *}$ & $-0.42^{* * * *}$ & $-0.42^{* * *}$ & $-0.43^{* * *}$ & $-0.42^{* * * *}$ & $-0.42^{* * * *}$ & $-0.42^{* * * *}$ \\
\hline Drain & -0.19 & -0.2 & -0.19 & -0.19 & -0.19 & -0.19 & -0.19 & -0.18 \\
\hline Cloud & 0.02 & 0.02 & 0.02 & 0.02 & 0.02 & 0.02 & 0.02 & 0.02 \\
\hline Solar & 0 & 0 & 0 & 0 & 0 & 0 & 0 & 0 \\
\hline Temp & $0.02^{* *}$ & $0.02^{* *}$ & $0.02^{* *}$ & $0.02^{* *}$ & $0.02^{* *}$ & $0.02^{* *}$ & $0.02^{* *}$ & $0.02^{* *}$ \\
\hline DMon & 0.02 & 0.02 & 0.02 & 0.02 & 0.02 & 0.02 & 0.02 & 0.02 \\
\hline $\operatorname{Adj}-R^{2}$ & $0.3351^{\text {*** }}$ & $0.3353^{* * * *}$ & $0.3353^{* * * *}$ & $0.3353^{* * * *}$ & $0.3348^{* * * * *}$ & $0.3354^{* * * *}$ & $0.3366^{* * * *}$ & $0.3381^{* * *}$ \\
\hline $\mathrm{Vol}_{\mathrm{GK}, \mathrm{t}}$ & 17 & 18 & 19 & 20 & 21 & 22 & 23 & 24 \\
\hline$\overline{a_{0}}$ & $8.96^{* * * *}$ & $8.95^{* * * * *}$ & $8.95^{* * * *}$ & $8.95^{* * * *}$ & $8.89^{* * * *}$ & $8.88^{* * * * *}$ & $8.87^{* * * *}$ & $8.85^{* * * *}$ \\
\hline $\mathrm{CO}$ & $-0.01^{*}$ & & & & & & & \\
\hline mean3CO & & $-0.01^{*}$ & & & & & & \\
\hline mean5CO & & & -0.01 & & & & & \\
\hline mean7CO & & & & -0.01 & & & & \\
\hline $\mathrm{SO}_{2}$ & & & & & 0.01 & & & \\
\hline mean $3 \mathrm{SO}_{2}$ & & & & & & $0.02^{* *}$ & & \\
\hline mean $5 \mathrm{SO}_{2}$ & & & & & & & $0.04^{* * * *}$ & \\
\hline mean $7 \mathrm{SO}_{2}$ & & & & & & & & $0.06^{* * * *}$ \\
\hline $\mathrm{R}_{\mathrm{m}}$ & $-0.43^{* * * *}$ & $-0.43^{* * * *}$ & $-0.43^{\text {**** }}$ & $-0.43^{* * * *}$ & $-0.42^{* * * *}$ & $-0.42^{* * * *}$ & $-0.42^{* * * *}$ & $-0.42^{* * * *}$ \\
\hline Drain & -0.24 & -0.22 & -0.21 & -0.21 & -0.15 & -0.14 & -0.15 & -0.13 \\
\hline Cloud & 0.02 & 0.02 & 0.02 & 0.02 & 0.02 & 0.02 & 0.02 & 0.02 \\
\hline Solar & -0.01 & -0.01 & -0.01 & -0.01 & 0 & 0 & 0 & 0 \\
\hline Temp & $0.02^{* * *}$ & $0.02^{* *}$ & $0.02^{* *}$ & $0.02^{* *}$ & $0.02^{* *}$ & $0.02^{* * *}$ & $0.02^{* *}$ & $0.02^{* *}$ \\
\hline DMon & 0.01 & 0.02 & 0.02 & 0.02 & 0.03 & 0.03 & 0.02 & 0.03 \\
\hline Adj- $R^{2}$ & $0.3368^{* * * *}$ & $0.3368^{* * * *}$ & $0.3366^{* * * *}$ & $0.3361^{* * * *}$ & $0.3361^{\text {**** }}$ & $0.3389^{\text {**** }}$ & $0.3430^{* * * *}$ & $0.3473^{* * * *}$ \\
\hline
\end{tabular}

\section{6 대기오염물질의 장기간노출과 투자자별 거래비중이 주식시장에 미치는 영향}

앞선 제 5.5절을 통해 대기오염의 장기간노출이 지수변동성에 미치는 영향을 확인 하였다. 본 절에서는 제 5.4 절에서의 대기오염물질 $\left(\mathrm{Ap}_{\mathrm{j}, t}\right)$ 을 대기오염물질의 $p$ 일 이동평균 (meanpAP $\mathrm{j}_{\mathrm{j}, \mathrm{t}}, p=3,5,7$ )로 대체하여 대기오염물질의 장기간노출과 투자자 유형별 거래 비중이 지수수익률 및 변동성에 미치는 영향을 알아보고자 한다. 분석 결과는 <표 22> <표 24>에서 확인할 수 있다.

제 5.4절에서의 회귀분석 결과에서는 지수수익률에 유의한 영향을 미치는 대기오염물질은 존재하지 않았으나, 초미세먼지와 이산화질소와 일산화탄소에 장기간노출시에 지수수익률이 감소하는 결과를 확인할 수 있었다. 즉, 초미세먼지에 5일 노출되었거나 이산화질소와 
Air Pollution, Stock Return, and Volatility

일산화탄소에 5 일 이상 노출되면 지수수익률이 감소하였으며, 이 중 5 일 노출되었을 때 지수수익률에 미치는 영향이 가장 크게 나타났다. 본 결과는 대기오염물질과 주가수익률 간에 음(-)의 상관관계가 나타난다는 기존 연구의 결과와 일치한다(Levy and Yagil, 2011; Lepori, 2009; Li and Peng, 2016).

또한 대기오염물질의 노출기간이 길수록 지수변동성에 더 많은 영향력을 행사하는 것을 알 수 있었다. 미세먼지와 초미세먼지, 오존의 농도가 높을수록 역사적변동성은 감소하였고 이산화질소의 농도가 높을수록 역사적변동성은 증가하였으며, 노출기간이 길수록 역사적 변동성의 추정치에 미치는 영향은 크게 나타났다. 특히, 미세먼지의 경우에는 당일 노출 시에는 영향이 없었으나 7일 이상 지속적으로 노출되면 역사적변동성이 감소했다.

범위기반변동성의 경우에도 유사한 결과를 나타냈다. 미세먼지와 초미세먼지의 농도가 높을수록 범위기반변동성은 감소하였고 이산화질소와 아황산가스의 농도가 높을수록 범위 기반변동성은 증가하였으며, 노출기간이 길수록 범위기반변동성의 추정치에 미치는 영향은 크게 나타났다. 특히, 이산화질소에 당일노출시 변동성에 미치는 영향이 없었으나 5일 이상 장기간 노출되면 범위기반변동성이 증가하였다. 그러나 미세먼지는 3 일 이하 노출시에 범위 기반변동성이 감소하였으나 오히려 장기간 노출하자 변동성에 영향이 없었다.

한편, 지수수익률은 개인투자자의 매도비중과 기관투자자의 매수비중과 음(-)의 상관 관계를 나타냈고 지수변동성은 개인투자자와 기관투자자의 매수비중과는 양 $(+)$ 의 상관관계를, 개인투자자와 기관투자자의 매도비중과는 음(-)의 상관관계를 나타냈다. 각 투자자별 매수 비중이 지수변동성에 미치는 영향은 비슷하였으나, 개인투자자보다 기관투자자의 매도비중이 지수변동성에 미치는 영향이 더 큰 것으로 나타났다. 이는 투자자 유형별 거래비중에 따라서 지수수익률 및 변동성에 대한 대기오염물질의 영향력이 상이함을 의미한다.

〈표 22〉 대기오염물질의 장기간노출과 투자자별 거래비중이 수익률에 미치는 영향 *** ****는 각각 $1 \%, 5 \%, 10 \%$ 수준에서 통계적으로 유의함을 의미함.

\begin{tabular}{|c|c|c|c|c|c|c|c|c|}
\hline $\mathrm{R}_{\mathrm{t}}$ & 1 & 2 & 3 & 4 & 5 & 6 & 7 & 8 \\
\hline$a_{0}$ & $1.23^{* * *}$ & $1.21^{* * *}$ & $1.24^{* * * *}$ & $1.23^{* * * *}$ & $1.23^{* * * *}$ & $1.21^{* * * *}$ & $1.23^{* * * *}$ & $1.23^{* * * *}$ \\
\hline $\mathrm{PM}_{10}$ & 0 & & & & & & & \\
\hline mean $3 \mathrm{PM}_{10}$ & & 0 & & & & & & \\
\hline mean5 $\mathrm{PM}_{10}$ & & & 0 & & & & & \\
\hline mean7PM 10 & & & & 0 & & & & \\
\hline $\mathrm{PM}_{2.5}$ & & & & & 0 & & & \\
\hline mean3PM 2.5 & & & & & & 0 & & \\
\hline mean $5 \mathrm{PM}_{2.5}$ & & & & & & & $-0.01^{*}$ & \\
\hline mean7PM 2.5 & & & & & & & & 0 \\
\hline $\mathrm{TR}_{\mathrm{B} \text {,ind }}$ & 0 & 0 & 0 & 0 & 0 & 0 & 0 & 0 \\
\hline $\mathrm{TR}_{\mathrm{S} \text {,ind }}$ & $-0.02^{* *}$ & $-0.02^{*}$ & $-0.01^{*}$ & $-0.02^{*}$ & $-0.02^{* *}$ & $-0.01^{*}$ & $-0.01^{*}$ & $-0.02^{*}$ \\
\hline $\mathrm{TR}_{\mathrm{B}, \mathrm{ins}}$ & $-0.02^{* *}$ & $-0.02^{* *}$ & $-0.02^{* * *}$ & $-0.02^{* *}$ & $-0.02^{* *}$ & $-0.02^{* *}$ & $-0.02^{* * * *}$ & $-0.02^{* * * *}$ \\
\hline $\mathrm{TR}_{\mathrm{S} \text {,ins }}$ & 0 & 0 & 0 & 0 & 0 & 0 & 0 & 0 \\
\hline $\mathrm{R}_{\mathrm{m}}$ & 0 & 0 & 0 & 0 & 0 & 0 & 0 & 0 \\
\hline Drain & -0.08 & -0.09 & -0.09 & -0.09 & -0.08 & -0.09 & -0.1 & -0.09 \\
\hline
\end{tabular}


한국증권학회지 제49권 3호 (2020)

〈표 22〉 대기오염물질의 장기간노출과 투자자별 거래비중이 수익률에 미치는 영향(계속)

\begin{tabular}{|c|c|c|c|c|c|c|c|c|}
\hline $\mathrm{R}_{\mathrm{t}}$ & 1 & 2 & 3 & 4 & 5 & 6 & 7 & 8 \\
\hline Cloud & 0 & 0 & 0 & 0 & 0 & 0 & 0 & 0 \\
\hline Solar & 0 & 0 & 0 & 0 & 0 & 0 & 0 & 0 \\
\hline Temp & 0 & 0 & 0 & 0 & 0 & 0 & 0 & 0 \\
\hline DMon & $-0.11^{*}$ & $-0.11^{*}$ & $-0.11^{*}$ & $-0.11^{*}$ & $-0.11^{*}$ & $-0.11^{*}$ & $-0.11^{*}$ & $-0.11^{*}$ \\
\hline$\underline{A d j-R^{2}}$ & $0.0131^{* *}$ & $0.0114^{* *}$ & $0.0132^{* *}$ & $0.0120^{* *}$ & $0.0127^{* *}$ & $0.0117^{* *}$ & $0.0154^{* * * *}$ & $0.0130^{* *}$ \\
\hline $\mathrm{R}_{\mathrm{t}}$ & 9 & 10 & 11 & 12 & 13 & 14 & 15 & 16 \\
\hline$\overline{a_{0}}$ & $1.22^{* * * *}$ & $1.23^{* * * *}$ & $1.22^{* * * *}$ & $1.21^{* * * *}$ & $1.22^{* * * *}$ & $1.26^{* * * *}$ & $1.30^{* * * * *}$ & $1.25^{* * *}$ \\
\hline $\mathrm{O}_{3}$ & 0 & & & & & & & \\
\hline mean $3 \mathrm{O}_{3}$ & & 0 & & & & & & \\
\hline mean $5 \mathrm{O}_{3}$ & & & 0 & & & & & \\
\hline mean $7 \mathrm{O}_{3}$ & & & & 0 & & & & \\
\hline $\mathrm{NO}_{2}$ & & & & & 0 & & & \\
\hline mean $3 \mathrm{NO}_{2}$ & & & & & & -0.01 & & \\
\hline mean $5 \mathrm{NO}_{2}$ & & & & & & & $-0.01^{* * * *}$ & \\
\hline mean7 $\mathrm{NO}_{2}$ & & & & & & & & $-0.01^{*}$ \\
\hline $\mathrm{TR}_{\mathrm{B}, \mathrm{ind}}$ & 0 & 0 & 0 & 0 & 0 & 0 & 0 & 0 \\
\hline $\mathrm{TR}_{\mathrm{S} \text {,ind }}$ & $-0.02^{*}$ & $-0.02^{*}$ & $-0.02^{*}$ & $-0.02^{*}$ & $-0.02^{*}$ & $-0.02^{*}$ & $-0.02^{*}$ & $-0.02^{*}$ \\
\hline $\mathrm{TR}_{\mathrm{B}, \mathrm{ins}}$ & $-0.02^{* *}$ & $-0.02^{* *}$ & $-0.02^{* *}$ & $-0.02^{* *}$ & $-0.02^{* *}$ & $-0.02^{* * * *}$ & $-0.02^{* * * *}$ & $-0.02^{* *}$ \\
\hline $\mathrm{TR}_{\mathrm{S} \text {,ins }}$ & 0 & 0 & 0 & 0 & 0 & 0 & 0 & 0 \\
\hline $\mathrm{R}_{\mathrm{m}}$ & 0 & 0 & 0 & 0 & 0 & 0 & -0.01 & 0 \\
\hline Drain & -0.09 & -0.09 & -0.09 & -0.09 & -0.1 & -0.1 & -0.1 & -0.1 \\
\hline Cloud & 0 & 0 & 0 & 0 & 0 & 0 & 0 & 0 \\
\hline Solar & 0 & 0 & 0 & 0 & 0 & 0 & 0 & 0 \\
\hline Temp & 0 & 0 & 0 & 0 & 0 & 0 & 0 & 0 \\
\hline DMon & $-0.11^{*}$ & $-0.11^{*}$ & $-0.11^{*}$ & $-0.11^{*}$ & $-0.11^{*}$ & $-0.11^{*}$ & $-0.11^{*}$ & $-0.11^{*}$ \\
\hline Adj-R & $0.0117^{* *}$ & $0.0119^{* *}$ & $0.0119^{* *}$ & $0.0114^{* *}$ & $0.0119^{* *}$ & $0.0139^{* *}$ & $0.0196^{* * * *}$ & $0.0144^{* * * *}$ \\
\hline $\mathrm{R}_{\mathrm{t}}$ & 17 & 18 & 19 & 20 & 21 & 22 & 23 & 24 \\
\hline$\overline{a_{0}}$ & $1.21^{* * * *}$ & $1.24^{* * * *}$ & $1.27^{* * * *}$ & $1.23^{* * * *}$ & $1.22^{* * * *}$ & $1.22^{* * * *}$ & $1.26^{* * * *}$ & $1.24^{* * *}$ \\
\hline $\mathrm{CO}$ & 0 & & & & & & & \\
\hline mean3CO & & 0 & & & & & & \\
\hline mean5CO & & & $-0.01^{* * * * *}$ & & & & & \\
\hline mean7CO & & & & $-0.01^{*}$ & & & & \\
\hline $\mathrm{SO}_{2}$ & & & & & 0 & & & \\
\hline mean3SO 2 & & & & & & 0 & & \\
\hline mean5SO 2 & & & & & & & -0.01 & \\
\hline mean7 $7 \mathrm{SO}_{2}$ & & & & & & & & 0 \\
\hline $\mathrm{TR}_{\mathrm{B} \text {,ind }}$ & 0 & 0 & 0 & 0 & 0 & 0 & 0 & 0 \\
\hline $\mathrm{TR}_{\mathrm{S} \text {,ind }}$ & $-0.02^{*}$ & $-0.01^{*}$ & $-0.02^{*}$ & $-0.02^{*}$ & $-0.02^{*}$ & $-0.02^{*}$ & $-0.02^{*}$ & $-0.02^{*}$ \\
\hline $\mathrm{TR}_{\mathrm{B}, \mathrm{ins}}$ & $-0.02^{* *}$ & $-0.02^{* * * *}$ & $-0.02^{* * * *}$ & $-0.02^{* *}$ & $-0.02^{* *}$ & $-0.02^{* * *}$ & $-0.02^{* *}$ & $-0.02^{* *}$ \\
\hline $\mathrm{TR}_{\mathrm{S}, \text { ins }}$ & 0 & 0 & 0 & 0 & 0 & 0 & 0 & 0 \\
\hline $\mathrm{R}_{\mathrm{m}}$ & 0 & 0 & -0.01 & -0.01 & 0 & 0 & 0 & 0 \\
\hline Drain & -0.09 & -0.1 & -0.1 & -0.1 & -0.08 & -0.1 & -0.1 & -0.1 \\
\hline Cloud & 0 & 0 & 0 & 0 & 0 & 0 & 0 & 0 \\
\hline Solar & 0 & 0 & -0.01 & 0 & 0 & 0 & 0 & 0 \\
\hline Temp & 0 & 0 & 0 & 0 & 0 & 0 & 0 & 0 \\
\hline DMon & $-0.11^{*}$ & $-0.11^{*}$ & $-0.11^{*}$ & $-0.11^{*}$ & $-0.11^{*}$ & $-0.11^{*}$ & $-0.11^{*}$ & $-0.11^{*}$ \\
\hline $\operatorname{Adj}-R^{2}$ & $0.0114^{* *}$ & $0.0136^{* *}$ & $0.0201^{* * *}$ & $0.0145^{* * * *}$ & $0.0117^{* *}$ & $0.0117^{* *}$ & $0.0137^{* * *}$ & $0.0124^{* *}$ \\
\hline
\end{tabular}


Air Pollution, Stock Return, and Volatility

〈표 23〉 대기오염물질의 장기간노출과 투자자별 거래비중이 역사적변동성에 미치는 영향 ***, *** *는 각각 $1 \%, 5 \%, 10 \%$ 수준에서 통계적으로 유의함을 의미함.

\begin{tabular}{|c|c|c|c|c|c|c|c|c|}
\hline $\mathrm{Vol}_{h, t}$ & 1 & 2 & 3 & 4 & 5 & 6 & 7 & 8 \\
\hline$\overline{a_{0}}$ & $10.60^{\text {*a*k }}$ & $10.70^{* \text { sols }}$ & $10.75^{* * * * *}$ & $10.78^{* \text { *wak }}$ & $10.51^{\text {***; }}$ & $10.64^{* 0 * \pi}$ & $10.78^{* * * *}$ & $10.85^{* * * *}$ \\
\hline $\mathrm{PM}_{10}$ & -0.01 & & & & & & & \\
\hline mean3PM ${ }_{10}$ & & -0.01 & & & & & & \\
\hline mean5 $\mathrm{PM}_{10}$ & & & -0.01 & & & & & \\
\hline mean7PM 10 & & & & $-0.02^{* *}$ & & & & \\
\hline $\mathrm{PM}_{2.5}$ & & & & & $-0.02^{* * *}$ & & & \\
\hline mean $3 \mathrm{PM}_{2.5}$ & & & & & & $-0.03^{* \text { *at* }}$ & & \\
\hline mean5PM 2.5 & & & & & & & $-0.04^{\text {**** }}$ & \\
\hline mean7PM ${ }_{2.5}$ & & & & & & & & $-0.06^{* * *}$ \\
\hline $\mathrm{TR}_{\mathrm{B}, \text { ind }}$ & $0.11^{* * k_{*}^{*}}$ & $0.11^{* * * * *}$ & $0.11^{* * * *}$ & $0.11^{* * * *}$ & $0.11^{* * * * * *}$ & $0.11^{* * * * *}$ & $0.11^{* * * * *}$ & $0.11^{* * *}$ \\
\hline $\mathrm{TR}_{\mathrm{S} \text {,ind }}$ & $-0.07^{* *}$ & $-0.07^{* * *}$ & $-0.07^{* *}$ & $-0.07^{* *}$ & $-0.07^{* * *}$ & $-0.07^{* *}$ & $-0.07^{* * *}$ & $-0.07^{* *}$ \\
\hline $\mathrm{TR}_{\mathrm{B}, \mathrm{ins}}$ & $0.10^{* * k^{*}}$ & $0.10^{* \text { *wak }}$ & 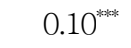 & 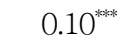 & $0.10^{\text {*wak }}$ & $0.09^{* * * * *}$ & $0.09^{* * * * * *}$ & $0.09^{* * * * *}$ \\
\hline $\mathrm{TR}_{\mathrm{S}, \mathrm{ins}}$ & $-0.10^{\text {*wak }}$ & $-0.10^{* \text { *opk }}$ & $-0.10^{\text {watak }}$ & $-0.10^{\text {*ask }}$ & $-0.10^{\text {*al }}$ & $-0.10^{\text {sot }}$ & $-0.10^{* \text { *ask }}$ & $-0.10^{* \text { *⿻; }}$ \\
\hline $\mathrm{R}_{\mathrm{m}}$ & $-0.64^{* * * a *}$ & $-0.65^{\text {*⿻丷木 }}$ & $-0.65^{\text {wetek }}$ & $-0.64^{\text {*oskes }}$ & $-0.65^{\text {**ak }}$ & $-0.65^{* * * * *}$ & $-0.65^{\text {**osk }}$ & $-0.66^{* * *}$ \\
\hline Drain & -0.31 & -0.29 & -0.28 & -0.28 & -0.32 & -0.31 & -0.3 & -0.31 \\
\hline Cloud & 0.04 & 0.04 & 0.04 & 0.04 & 0.05 & 0.05 & 0.05 & 0.04 \\
\hline Solar & -0.03 & -0.03 & -0.03 & -0.03 & -0.03 & -0.03 & -0.03 & -0.03 \\
\hline Temp & $-0.03^{* * *}$ & $-0.03^{* * *}$ & $-0.03^{* * *}$ & $-0.03^{* * k}$ & $-0.03^{* * *}$ & $-0.03^{* *}$ & $-0.03^{* *}$ & $-0.03^{* *}$ \\
\hline DMon & 0.15 & 0.14 & 0.14 & 0.14 & 0.15 & 0.14 & 0.13 & 0.14 \\
\hline $\operatorname{Adj}-R^{2}$ & $0.3552^{* * * * *}$ & $0.3558^{* * * * *}$ & $0.3558^{* * * * *}$ & $0.3571^{* * * *}$ & $0.3568^{* * * * *}$ & $0.3589^{* * * *}$ & $0.3618^{* * * * *}$ & $0.3656^{* * * *}$ \\
\hline $\mathrm{Vol}_{\mathrm{h}, \mathrm{t}}$ & 9 & 10 & 11 & 12 & 13 & 14 & 15 & 16 \\
\hline$\overline{a_{0}}$ & $10.52^{\text {*w*k }}$ & $10.44^{* * a+k}$ & $10.48^{\text {*tek* }}$ & $10.59^{* \text { *osk }}$ & $10.54^{\text {*aske }}$ & $10.36^{\text {stow }}$ & $10.34^{\text {*a*k }}$ & $10.47^{* * * *}$ \\
\hline $\mathrm{O}_{3}$ & $-0.03^{*}$ & & & & & & & \\
\hline mean $3 \mathrm{O}_{3}$ & & $-0.04^{* * *}$ & & & & & & \\
\hline mean $5 \mathrm{O}_{3}$ & & & $-0.05^{\text {wk }}$ & & & & & \\
\hline mean $7 \mathrm{O}_{3}$ & & & & $-0.05^{* *}$ & & & & \\
\hline $\mathrm{NO}_{2}$ & & & & & $0.02^{*}$ & & & \\
\hline mean3 $\mathrm{NO}_{2}$ & & & & & & $0.03^{* *}$ & & \\
\hline mean5 $\mathrm{NO}_{2}$ & & & & & & & $0.04^{* * *}$ & \\
\hline mean7 $\mathrm{NO}_{2}$ & & & & & & & & $0.04^{* * *}$ \\
\hline $\mathrm{TR}_{\mathrm{B} \text {,ind }}$ & $0.11^{* * * * * *}$ & 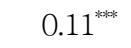 & $0.11^{\text {*⿻*; }}$ & $0.11^{* * * * *}$ & $0.11^{* * a k}$ & $0.11^{* * * * *}$ & $0.11^{* * * * *}$ & $0.11^{* * * * *}$ \\
\hline $\mathrm{TR}_{\mathrm{S}, \mathrm{ind}}$ & $-0.08^{* * *}$ & $-0.07^{* * *}$ & $-0.08^{* *}$ & $-0.08^{* * *}$ & $-0.08^{* *}$ & $-0.08^{* * *}$ & $-0.08^{* * *}$ & $-0.08^{* *}$ \\
\hline $\mathrm{TR}_{\mathrm{B} \text {,ins }}$ & $0.10^{* * * k}$ & $0.10^{* * * *}$ & $0.10^{* * * * *}$ & $0.10^{* * * *}$ & $0.10^{* * * * *}$ & 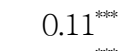 & $0.10^{\text {***** }}$ & $0.10^{* * * *}$ \\
\hline $\mathrm{TR}_{\mathrm{S}, \mathrm{ins}}$ & $-0.10^{\text {side }}$ & $-0.10^{* \text { *ask }}$ & $-0.11^{\text {voles }}$ & 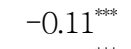 & $-0.10^{* * * * *}$ & $-0.10^{* a n}$ & $-0.10^{\text {䖩水 }}$ & $-0.10^{* * * *}$ \\
\hline $\mathrm{R}_{\mathrm{m}}$ & $-0.64^{* \text { **a* }}$ & $-0.63^{\text {***⿰冫中⿰㇀丶㇀ }}$ & $-0.63^{\text {w**** }}$ & 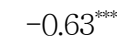 & $-0.64^{* * * * k}$ & $-0.64^{* * * * *}$ & $-0.63^{* * * * *}$ & $-0.63^{* \text { *⿻; }}$ \\
\hline Drain & -0.24 & -0.25 & -0.23 & -0.23 & -0.18 & -0.22 & -0.24 & -0.24 \\
\hline Cloud & 0.04 & 0.04 & 0.04 & 0.04 & 0.03 & 0.03 & 0.03 & 0.04 \\
\hline Solar & -0.01 & -0.01 & -0.01 & -0.02 & -0.02 & -0.02 & -0.02 & -0.02 \\
\hline Temp & $-0.03^{* * *}$ & $-0.03^{* * *}$ & $-0.03^{* *}$ & $-0.03^{\text {w*k }}$ & $-0.03^{* *}$ & $-0.03^{* *}$ & $-0.03^{* *}$ & $-0.03^{* *}$ \\
\hline DMon & 0.13 & 0.15 & 0.14 & 0.14 & 0.16 & 0.14 & 0.15 & 0.15 \\
\hline Adj-R ${ }^{2}$ & $0.3563^{* * * * *}$ & $0.3585^{* * * * *}$ & $0.3585^{\text {***:* }}$ & $0.3573^{* * * * *}$ & $0.3561^{\text {**ak }}$ & $0.3578^{* * * * *}$ & $0.3579^{* * * * *}$ & $0.3572^{* * * *}$ \\
\hline $\mathrm{Vol}_{\mathrm{h}, \mathrm{t}}$ & 17 & 18 & 19 & 20 & 21 & 22 & 23 & 24 \\
\hline $\mathrm{a}_{0}$ & $10.64^{\text {**** }}$ & $10.64^{* * * * * *}$ & $10.68^{\text {*a*k }}$ & 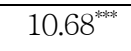 & $10.67^{\text {wok }}$ & $10.54^{* * * * *}$ & $10.48^{* * * * k}$ & $10.52^{* * * * *}$ \\
\hline $\mathrm{CO}$ & 0 & & & & & & & \\
\hline mean3CO & & 0 & & & & & & \\
\hline mean5CO & & & -0.01 & & & & & \\
\hline
\end{tabular}


한국증권학회지 제49권 3호 (2020)

〈표 23〉 대기오염물질의 장기간노출과 투자자별 거래비중이 역사적변동성에 미치는 영향(계속)

\begin{tabular}{|c|c|c|c|c|c|c|c|c|}
\hline $\mathrm{Vol}_{\mathrm{h}, \mathrm{t}}$ & 17 & 18 & 19 & 20 & 21 & 22 & 23 & 24 \\
\hline mean7CO & & & & -0.01 & & & & \\
\hline $\mathrm{SO}_{2}$ & & & & & 0.01 & & & \\
\hline mean $3 \mathrm{SO}_{2}$ & & & & & & 0.02 & & \\
\hline mean $5 \mathrm{SO}_{2}$ & & & & & & & 0.03 & \\
\hline mean7 $\mathrm{SO}_{2}$ & & & & & & & & 0.02 \\
\hline $\mathrm{TR}_{\mathrm{B} \text {,ind }}$ & $0.11^{\text {*ale }}$ & $0.11^{\text {*a*k }}$ & $0.11^{* * * * *}$ & $0.11^{* * * * * *}$ & 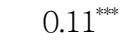 & $0.11^{* * * * *}$ & $0.11^{* * * * *}$ & $0.11^{* * * *}$ \\
\hline $\mathrm{TR}_{\mathrm{S} \text {,ind }}$ & $-0.08^{* *}$ & $-0.08^{* * *}$ & $-0.08^{* * *}$ & $-0.08^{* * *}$ & $-0.08^{* *}$ & $-0.08^{* *}$ & $-0.08^{* *}$ & $-0.08^{* *}$ \\
\hline $\mathrm{TR}_{\mathrm{B}, \mathrm{ins}}$ & $0.10^{* * k+k}$ & $0.10^{\text {skat }}$ & 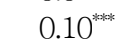 & $0.10^{* \text { *os }}$ & $0.10^{\text {sopk }}$ & $0.10^{* * *}$ & $0.10^{* * * k}$ & $0.10^{* * * * *}$ \\
\hline $\mathrm{TR}_{\mathrm{S}, \mathrm{ins}}$ & $-0.10^{\text {*kak }}$ & $-0.10^{* * * * *}$ & $-0.10^{* * * * *}$ & 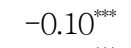 & $-0.10^{* * * * *}$ & $-0.10^{\text {wak }}$ & $-0.10^{* * * *}$ & $-0.10^{* \text { *a* }}$ \\
\hline $\mathrm{R}_{\mathrm{m}}$ & $-0.64^{\text {*wak }}$ & $-0.64^{* * * * *}$ & $-0.64^{* * * * *}$ & $-0.65^{\text {**ak }}$ & $-0.64^{* \text { *ak }}$ & $-0.64^{* w a k}$ & $-0.64^{* * * * *}$ & $-0.64^{* \text { *wok }}$ \\
\hline Drain & -0.27 & -0.27 & -0.27 & -0.28 & -0.21 & -0.22 & -0.24 & -0.24 \\
\hline Cloud & 0.04 & 0.04 & 0.04 & 0.04 & 0.04 & 0.04 & 0.04 & 0.04 \\
\hline Solar & -0.03 & -0.03 & -0.03 & -0.03 & -0.02 & -0.02 & -0.02 & -0.03 \\
\hline Temp & $-0.03^{* * *}$ & $-0.03^{* *}$ & $-0.03^{* * *}$ & $-0.03^{* *}$ & $-0.03^{* *}$ & $-0.03^{* *}$ & $-0.03^{* *}$ & $-0.03^{* *}$ \\
\hline DMon & 0.14 & 0.14 & 0.14 & 0.14 & 0.15 & 0.15 & 0.14 & 0.14 \\
\hline Adj-R ${ }^{2}$ & $0.3541^{\text {**ak }}$ & $0.3541^{\text {**ak }}$ & $0.3543^{\text {***** }}$ & $0.3548^{* * * * *}$ & $0.3548^{\text {***ak }}$ & $0.3554^{* * * *}$ & $0.3555^{\text {**** }}$ & $0.3551^{\text {*** }}$ \\
\hline
\end{tabular}

〈표 24〉대기오염물질의 장기간노출과 투자자별 거래비중이 범위기반변동성에 미치는 영향 *** ,** *는 각각 $1 \%, 5 \%, 10 \%$ 수준에서 통계적으로 유의함을 의미함.

\begin{tabular}{|c|c|c|c|c|c|c|c|c|}
\hline $\mathrm{Vol}_{\mathrm{GK}, \mathrm{t}}$ & 1 & 2 & 3 & 4 & 5 & 6 & 7 & 8 \\
\hline$\overline{a_{0}}$ & $8.42^{* * * *}$ & $8.50^{* * * *}$ & $8.52^{* * * *}$ & $8.50^{* \text { *a*k }}$ & $8.35^{* * * *}$ & $8.46^{* k * k}$ & $8.56^{* * * k}$ & $8.58^{* k+k n}$ \\
\hline $\mathrm{PM}_{10}$ & $-0.01^{*}$ & & & & & & & \\
\hline mean3 $3 \mathrm{PM}_{10}$ & & $-0.01^{*}$ & & & & & & \\
\hline mean5 $\mathrm{PM}_{10}$ & & & -0.01 & & & & & \\
\hline mean7PM 10 & & & & -0.01 & & & & \\
\hline $\mathrm{PM}_{2.5}$ & & & & & $-0.01^{* * * *}$ & & & \\
\hline mean $3 \mathrm{PM}_{2.5}$ & & & & & & $-0.02^{* * * * * *}$ & & \\
\hline mean5PM 2.5 & & & & & & & $-0.03^{\text {wetek }}$ & \\
\hline mean7(PM 2.5 & & & & & & & & $-0.03^{\text {*x+k }}$ \\
\hline $\mathrm{TR}_{\mathrm{B} \text {,ind }}$ & $0.06^{* * * k}$ & $0.06^{* * * *}$ & $0.06^{* * * *}$ & $0.07^{* * * *}$ & $0.06^{* * *}$ & $0.06^{* * * * *}$ & $0.06^{* * * *}$ & $0.07^{* * * * 4}$ \\
\hline $\mathrm{TR}_{\text {S,ind }}$ & $-0.05^{* * *}$ & $-0.05^{* *}$ & $-0.05^{* *}$ & $-0.05^{* *}$ & $-0.05^{* *}$ & $-0.04^{* *}$ & $-0.05^{* *}$ & $-0.05^{* *}$ \\
\hline $\mathrm{TR}_{\mathrm{B}, \mathrm{ins}}$ & $0.07^{* * * * k}$ & $0.07^{* * * * *}$ & $0.07^{* * * * *}$ & $0.08^{* * * * * *}$ & $0.07^{* * * * *}$ & 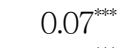 & 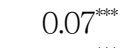 & $0.07^{\text {water }}$ \\
\hline $\mathrm{TR}_{\text {S,ins }}$ & $-0.09^{\text {*atak }}$ & $-0.09^{* * * * *}$ & $-0.09^{* \text { *ow }}$ & $-0.09^{* * * * *}$ & $-0.09^{* * * *}$ & $-0.09^{* * * * *}$ & $-0.09^{\text {*atak }}$ & $-0.09^{* * * * *+1}$ \\
\hline $\mathrm{R}_{\mathrm{m}}$ & $-0.42^{\text {wate }}$ & $-0.42^{* * * *}$ & $-0.42^{\text {swa* }}$ & $-0.42^{\text {*w** }}$ & $-0.42^{* * * *}$ & $-0.42^{* * * * *}$ & $-0.42^{\text {wete }}$ & $-0.42^{* \text { wax }}$ \\
\hline Drain & -0.28 & -0.25 & -0.24 & -0.24 & -0.28 & -0.27 & -0.25 & -0.26 \\
\hline Cloud & 0.02 & 0.02 & 0.02 & 0.02 & 0.03 & 0.02 & 0.02 & 0.02 \\
\hline Solar & -0.01 & -0.01 & -0.01 & 0 & -0.01 & -0.01 & -0.01 & -0.01 \\
\hline Temp & $0.02^{* * *}$ & $0.02^{* * *}$ & $0.02^{* * *}$ & $0.02^{* * *}$ & $0.02^{* *}$ & $0.02^{* *}$ & $0.02^{* * *}$ & $0.02^{* *}$ \\
\hline DMon & 0.03 & 0.02 & 0.02 & 0.03 & 0.03 & 0.03 & 0.02 & 0.02 \\
\hline $\mathrm{Adj} \mathrm{R}^{2}$ & $0.3512^{* * * * *}$ & $0.3511^{* * * *}$ & $0.3502^{* * * *}$ & $0.3497^{\text {**** }}$ & $0.3539^{* * *}$ & $0.3553^{* * a k}$ & $0.3570^{* * * * *}$ & 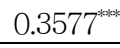 \\
\hline Vol $_{\mathrm{GK}, \mathrm{t}}$ & 9 & 10 & 11 & 12 & 13 & 14 & 15 & 16 \\
\hline $\mathrm{a}_{0}$ & $8.42^{* * * *}$ & $8.41^{* * * *}$ & $8.42^{* * * *}$ & $8.45^{* * * *}$ & $8.45^{* * * *}$ & $8.37^{* * * * *}$ & $8.32^{* * * *}$ & $8.35^{\text {keth }}$ \\
\hline $\mathrm{O}_{3}$ & -0.01 & & & & & & & \\
\hline mean $3 \mathrm{O}_{3}$ & & -0.01 & & & & & & \\
\hline mean5O & & & -0.02 & & & & & \\
\hline mean $7 \mathrm{O}_{3}$ & & & & -0.02 & & & & \\
\hline $\mathrm{NO}_{2}$ & & & & & 0 & & & \\
\hline
\end{tabular}


Air Pollution, Stock Return, and Volatility

〈표 24〉대기오염물질의 장기간노출과 투자자별 거래비중이 범위기반변동성에 미치는 영향(계속)

\begin{tabular}{|c|c|c|c|c|c|c|c|c|}
\hline Vol $_{\mathrm{GK}, \mathrm{t}}$ & 9 & 10 & 11 & 12 & 13 & 14 & 15 & 16 \\
\hline mean3NO & & & & & & 0.01 & & \\
\hline mean $5 \mathrm{NO}_{2}$ & & & & & & & $0.02^{*}$ & \\
\hline mean7 $\mathrm{NO}_{2}$ & & & & & & & & $0.03^{* * *}$ \\
\hline $\mathrm{TR}_{\mathrm{B}, \mathrm{ind}}$ & $0.07^{* \text { *Nak }}$ & $0.07^{* * * * *}$ & $0.07^{* * * * *}$ & $0.07^{* * * * *}$ & $0.07^{* * * * *}$ & $0.07^{* * * * * *}$ & $0.07^{* * * * * *}$ & $0.07^{\text {watent }}$ \\
\hline $\mathrm{TR}_{\text {S,ind }}$ & $-0.05^{* *}$ & $-0.05^{* *}$ & $-0.05^{* *}$ & $-0.05^{* *}$ & $-0.05^{* *}$ & $-0.05^{* *}$ & $-0.05^{\text {w* }}$ & $-0.05^{* * *}$ \\
\hline $\mathrm{TR}_{\mathrm{B}, \mathrm{ins}}$ & $0.08^{* \text { **** }}$ & $0.08^{* * * *}$ & $0.08^{* * * *}$ & $0.08^{* * * * *}$ & $0.08^{* * * * *}$ & $0.08^{* * * * *}$ & $0.08^{* \text { ****** }}$ & $0.08^{\text {watent }}$ \\
\hline $\mathrm{TR}_{\mathrm{S}, \mathrm{ins}}$ & $-0.09^{* * * * *}$ & $-0.09^{* * * * *}$ & $-0.09^{* * * *}$ & $-0.09^{\text {*atk }}$ & $-0.09^{* \text { *o* }}$ & $-0.09^{* * a k}$ & $-0.09^{\text {watk }}$ & $-0.09^{* * * * * *}$ \\
\hline $\mathrm{R}_{\mathrm{m}}$ & $-0.41^{* * * * *}$ & $-0.41^{* * * *}$ & $-0.41^{\text {**** }}$ & $-0.41^{\text {*atk }}$ & $-0.41^{* * * *}$ & $-0.41^{\text {*ask }}$ & $-0.41^{\text {sise }}$ & $-0.41^{* \text { *⿻一丿 }}$ \\
\hline Drain & -0.22 & -0.23 & -0.22 & -0.22 & -0.22 & -0.22 & -0.22 & -0.21 \\
\hline Cloud & 0.02 & 0.02 & 0.02 & 0.02 & 0.02 & 0.01 & 0.01 & 0.01 \\
\hline Solar & 0 & 0 & 0 & 0 & 0 & 0 & 0 & 0 \\
\hline Temp & $0.02^{* *}$ & $0.02^{* *}$ & $0.02^{* *}$ & $0.02^{* *}$ & $0.02^{* *}$ & $0.02^{* * *}$ & $0.02^{* * *}$ & $0.02^{* * *}$ \\
\hline DMon & 0.02 & 0.03 & 0.02 & 0.02 & 0.03 & 0.03 & 0.03 & 0.03 \\
\hline$\underline{A d j-R^{2}}$ & 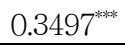 & $0.3499^{* * * *}$ & $0.3502^{* * * * *}$ & $0.3502^{* * * * *}$ & $0.3493^{\text {***** }}$ & $0.3500^{* \text { ***** }}$ & $0.3511^{* * * * *}$ & $0.3525^{* \text { *⿻一从火 }}$ \\
\hline Vol $_{\mathrm{GK}, \mathrm{t}}$ & 17 & 18 & 19 & 20 & 21 & 22 & 23 & 24 \\
\hline$a_{0}$ & $8.49^{* * * * *}$ & $8.52^{* * * * *}$ & $8.54^{* * * * *}$ & $8.50^{* * * * *}$ & $8.49^{* * * * *}$ & $8.33^{* * * * *}$ & $8.18^{* * * * *}$ & $8.17^{* \mathrm{kikn}}$ \\
\hline $\mathrm{CO}$ & -0.01 & & & & & & & \\
\hline mean3CO & & -0.01 & & & & & & \\
\hline mean5CO & & & -0.01 & & & & & \\
\hline mean7CO & & & & -0.01 & & & & \\
\hline $\mathrm{SO}_{2}$ & & & & & $0.01^{*}$ & & & \\
\hline mean $3 \mathrm{SO}_{2}$ & & & & & & $0.03^{* * * a k}$ & & \\
\hline mean5 $\mathrm{SO}_{2}$ & & & & & & & $0.04^{* * * * *}$ & \\
\hline mean7 $\mathrm{SO}_{2}$ & & & & & & & & $0.06^{\text {sitent }}$ \\
\hline $\mathrm{TR}_{\mathrm{B}, \mathrm{ind}}$ & $0.07^{* * 1 * k}$ & $0.06^{* * * *}$ & $0.07^{* * * * *}$ & $0.07^{* * * * *}$ & $0.07^{* * * *}$ & $0.07^{* * * \alpha}$ & $0.07^{* * * * * *}$ & $0.07^{\text {watent }}$ \\
\hline $\mathrm{TR}_{\mathrm{S} \text {,ind }}$ & $-0.05^{* *}$ & $-0.05^{* *}$ & $-0.05^{* *}$ & $-0.05^{* *}$ & $-0.05^{* *}$ & $-0.05^{* *}$ & $-0.05^{* * *}$ & $-0.05^{* *}$ \\
\hline $\mathrm{TR}_{\mathrm{B}, \mathrm{ins}}$ & $0.08^{* * * * *}$ & $0.08^{* * * * *}$ & $0.08^{* * * * *}$ & $0.08^{* \text { *⿻*k }}$ & $0.08^{* * * * *}$ & $0.08^{* * * * k}$ & $0.08^{* \text { ***** }}$ & $0.08^{*+\infty}$ \\
\hline $\mathrm{TR}_{\mathrm{S}, \mathrm{ins}}$ & $-0.09^{* * * * *}$ & $-0.09^{\text {******* }}$ & $-0.09^{* * * * *}$ & $-0.09^{\text {****** }}$ & $-0.09^{* * * * *}$ & $-0.09^{\text {**ak }}$ & $-0.09^{\text {iskik }}$ & $-0.09^{* * * * *}$ \\
\hline $\mathrm{R}_{\mathrm{m}}$ & $-0.42^{* * * *}$ & $-0.42^{* * * k}$ & $-0.42^{* * * * *}$ & $-0.42^{\text {*wak }}$ & $-0.41^{\text {**ak }}$ & $-0.41^{\text {*ask }}$ & $-0.41^{\text {so* }}$ & $-0.41^{* * * * *}$ \\
\hline Drain & -0.27 & -0.25 & -0.24 & -0.24 & -0.17 & -0.17 & -0.18 & -0.17 \\
\hline Cloud & 0.02 & 0.02 & 0.02 & 0.02 & 0.01 & 0.01 & 0.02 & 0.02 \\
\hline Solar & -0.01 & -0.01 & -0.01 & -0.01 & 0 & 0 & 0 & 0 \\
\hline Temp & $0.02^{* *}$ & $0.02^{* * *}$ & $0.02^{* *}$ & $0.02^{* * *}$ & $0.02^{* * *}$ & $0.02^{* * *}$ & $0.02^{* * *}$ & $0.02^{* * *}$ \\
\hline DMon & 0.02 & 0.02 & 0.02 & 0.02 & 0.04 & 0.04 & 0.03 & 0.03 \\
\hline Adj- $R^{2}$ & $0.3505^{\text {*** }}$ & $0.3505^{* * * *}$ & $0.3506^{* * *}$ & $0.3502^{* * * *}$ & $0.3510^{* * * *}$ & $0.3547^{\text {**** }}$ & $0.3589^{* * * * *}$ & 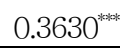 \\
\hline
\end{tabular}

\section{7 투자자 유형별 거래비중을 통한 대기오염물질의 간접효과}

제 5.3절과 제 5.4절을 통해 투자자 유형별 거래비중에 따라서 대기오염물질이 지수수익률 및 변동성에 미치는 영향이 달라지는 것을 알 수 있었다. 이에 본 절에서는 지수수익률 및 변동성에 미치는 요인으로 대기오염물질과 투자자 유형별 거래비중의 상호작용 항을 통해 대기오염물질의 간접 효과에 대하여 알아보고자 한다. 분석은 투자자 유형별로 개인, 기관, 외국인으로 나누어 분석한다. 각 유형별 거래비중을 통한 간접효과를 분석하기 위하여 상호작용항은 투자자유형별로 상이하다. 본 절에서의 분석 결과는 통계적으로 유의한 변수에 관해서만 기술하고 그 외는 생략하기로 한다. 분석에 사용한 회귀분석 식은 <표 25>와 
같으며 분석 결과는 <표 26> <표 28>에서 확인할 수 있다. 본 절에서는 이 때 설명변수로 사용된 투자자 유형별 거래비중은 내생성 문제 때문에 전일의 데이터를 사용하여 분석하였고 제 5.4절에서처럼 모든 투자자의 유형을 독립변수로 분석 시 다중 공선성의 문제가 발생할 수 있으므로 개인과 기관 두 유형에 대하여 분석하였다. $\mathrm{Dep}_{\mathrm{i}, \mathrm{t}}$ 는 종속변수를 나타내며 $\mathrm{i}$ 는 수익률 $\left(\mathrm{R}_{\mathrm{t}}\right)$, 역사적변동성 $\left(\mathrm{Vol}_{\mathrm{h}}\right)$, 범위기반변동성 $\left(\mathrm{Vol}_{\mathrm{GK}}\right)$ 이다. $\mathrm{Dep}_{\mathrm{i}, \mathrm{t}}$ 는 수익률 $\left(\mathrm{R}_{\mathrm{t}}\right)$, 역사적 변동성 $\left(\operatorname{Vol}_{\mathrm{h}, \mathrm{t}}\right)$, 범위기반변동성 $\left(\mathrm{Vol}_{\mathrm{GK}, \mathrm{t}}\right)$ 등 종속변수를 나타내며, 설명변수로 사용한 변수 들은 $\mathrm{AP}_{\mathrm{j}, \mathrm{t}}$ (대기오염물질 변수)와 $\mathrm{TR}_{\mathrm{l}, \mathrm{n}, \mathrm{t}-1}$ (전일의 투자자 유형별 거래비중), $\mathrm{AP}_{\mathrm{j}, \mathrm{t}} \cdot \mathrm{TR}_{\mathrm{l}, \mathrm{n}, \mathrm{t}-1}$ (대기 오염물질과 투자자 유형별 거래비중의 상호작용 항)이며 통제변수로는 $\mathrm{R}_{\mathrm{m}, \mathrm{t}}$ (전월 시장수익률), $\mathrm{W}_{\mathrm{k}, \mathrm{t}}$ (날씨변수), $\mathrm{DMon}_{\mathrm{t}}$ (요일 더미변수)를 사용하였다. 이 때, $\mathrm{j}$ 는 $\mathrm{PM}_{10}, \mathrm{PM}_{2.5}, \mathrm{O}_{3}, \mathrm{NO}_{2}, \mathrm{CO}$, $\mathrm{SO}_{2}$ 등 6 종류의 대기오염물질을, 1 은 매수(B), 매도(S) 등 거래형태를, $\mathrm{n}$ 은 개인(ind), 기관 (ins) 등 투자자 유형을, $\mathrm{k}$ 는 강수(Drain), 구름양(Cloud), 일사량(Solar), 기온(Temp) 등 날씨를 의미한다.

모형 1 은 개인의 거래비중을 통한 대기오염의 간접효과를, 모형 2 는 기관의 거래비중을 통한 간접효과를, 모형 3은 외국인의 거래비중을 통한 간접효과를 확인하기 위한 회귀분석 식이다. 개인투자자의 경우에는 지수수익률과 변동성에 대한 대기오염의 간접효과는 발견 되지 않았으나, 기관투자자와 외국인투자자의 경우에는 지수수익률과 변동성에 대하여 간접 효과가 발견되었다.

지수수익률에 대한 회귀분석 결과, 기관의 매도비중과 일산화탄소의 상호작용 $\left(\mathrm{TR}_{\mathrm{S}, \mathrm{ins}} \cdot \mathrm{CO}\right)$ 은 수익률과 유의한 양 $(+)$ 의 상관관계를 보였다. 개인투자자와 외국인투자자의 경우에는 지수 수익률에 대한 간접효과는 존재하지 않았다.

〈표 25〉모형의 회귀분석 식

\begin{tabular}{|c|c|}
\hline 모형번호 & 회귀분석 식 \\
\hline 1 & $\begin{aligned} \operatorname{Dep}_{\mathrm{i}, \mathrm{t}}= & \alpha_{0}+\sum_{\mathrm{j}=1}^{6} \alpha_{\mathrm{j}} \mathrm{AP}_{\mathrm{j}, \mathrm{t}}+\alpha_{7} R_{m, t}+\sum_{\mathrm{l}=1}^{2} \sum_{\mathrm{n}=1}^{2} \beta_{l, n} T R_{l, n, t-1}+\sum_{\mathrm{k}=8}^{11} \alpha_{\mathrm{k}} W_{k, t}+\alpha_{12} \mathrm{DMon}_{\mathrm{t}} \\
& +\sum_{j=1}^{6} \sum_{l=1}^{2} \gamma_{j, l} T R_{l, i n d, t-1} \cdot \mathrm{AP}_{j, \mathrm{t}}+\varepsilon_{\mathrm{t}}\end{aligned}$ \\
\hline 2 & $\begin{aligned} \operatorname{Dep}_{\mathrm{i}, \mathrm{t}}= & \alpha_{0}+\sum_{\mathrm{j}=1}^{6} \alpha_{\mathrm{j}} \mathrm{AP}_{\mathrm{j}, \mathrm{t}}+\alpha_{7} R_{m, t}+\sum_{\mathrm{l}=1}^{2} \sum_{\mathrm{n}=1}^{2} \beta_{l, n} T R_{l, n, t-1}+\sum_{\mathrm{k}=8}^{11} \alpha_{\mathrm{k}} W_{k, t}+\alpha_{12} \mathrm{DMon}_{\mathrm{t}} \\
& +\sum_{j=1}^{6} \sum_{l=1}^{2} \gamma_{j, l} T R_{l, i n s, t-1} \cdot \mathrm{AP}_{j, \mathrm{t}}+\varepsilon_{\mathrm{t}}\end{aligned}$ \\
\hline 3 & $\begin{aligned} \operatorname{Dep}_{\mathrm{i}, \mathrm{t}}= & \alpha_{0}+\sum_{\mathrm{j}=1}^{6} \alpha_{\mathrm{j}} \mathrm{AP}_{\mathrm{j}, \mathrm{t}}+\alpha_{7} R_{m, t}+\sum_{\mathrm{l}=1}^{2} \sum_{\mathrm{n}=1}^{2} \beta_{l, n} T R_{l, n, t-1}+\sum_{\mathrm{k}=8}^{11} \alpha_{\mathrm{k}} W_{k, t}+\alpha_{12} \mathrm{DMon}_{\mathrm{t}} \\
& +\sum_{j=1}^{6} \sum_{l=1}^{2} \gamma_{j, l} T R_{l, f o r, t-1} \cdot \mathrm{AP}_{j, \mathrm{t}}+\varepsilon_{\mathrm{t}}\end{aligned}$ \\
\hline
\end{tabular}




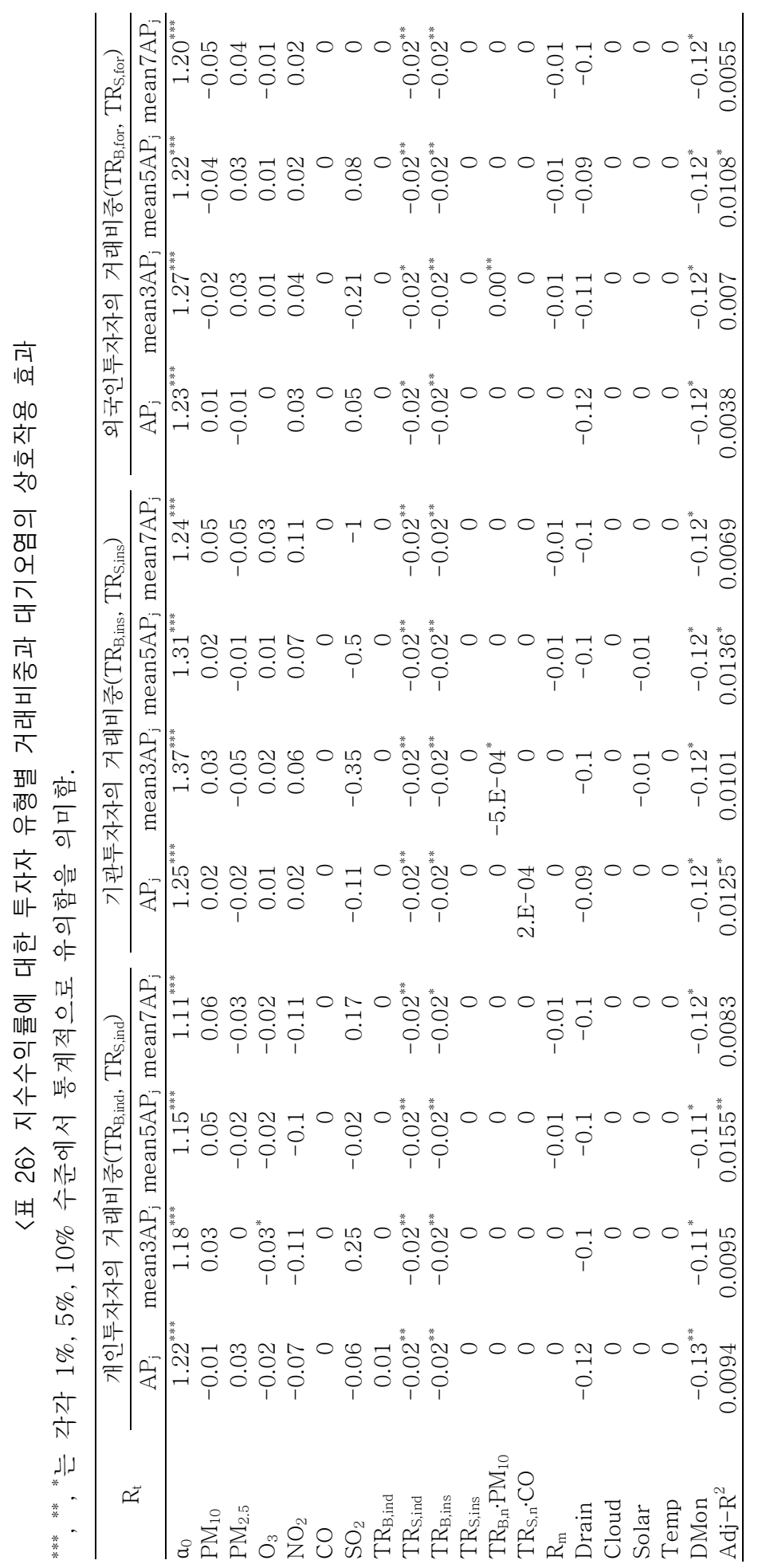




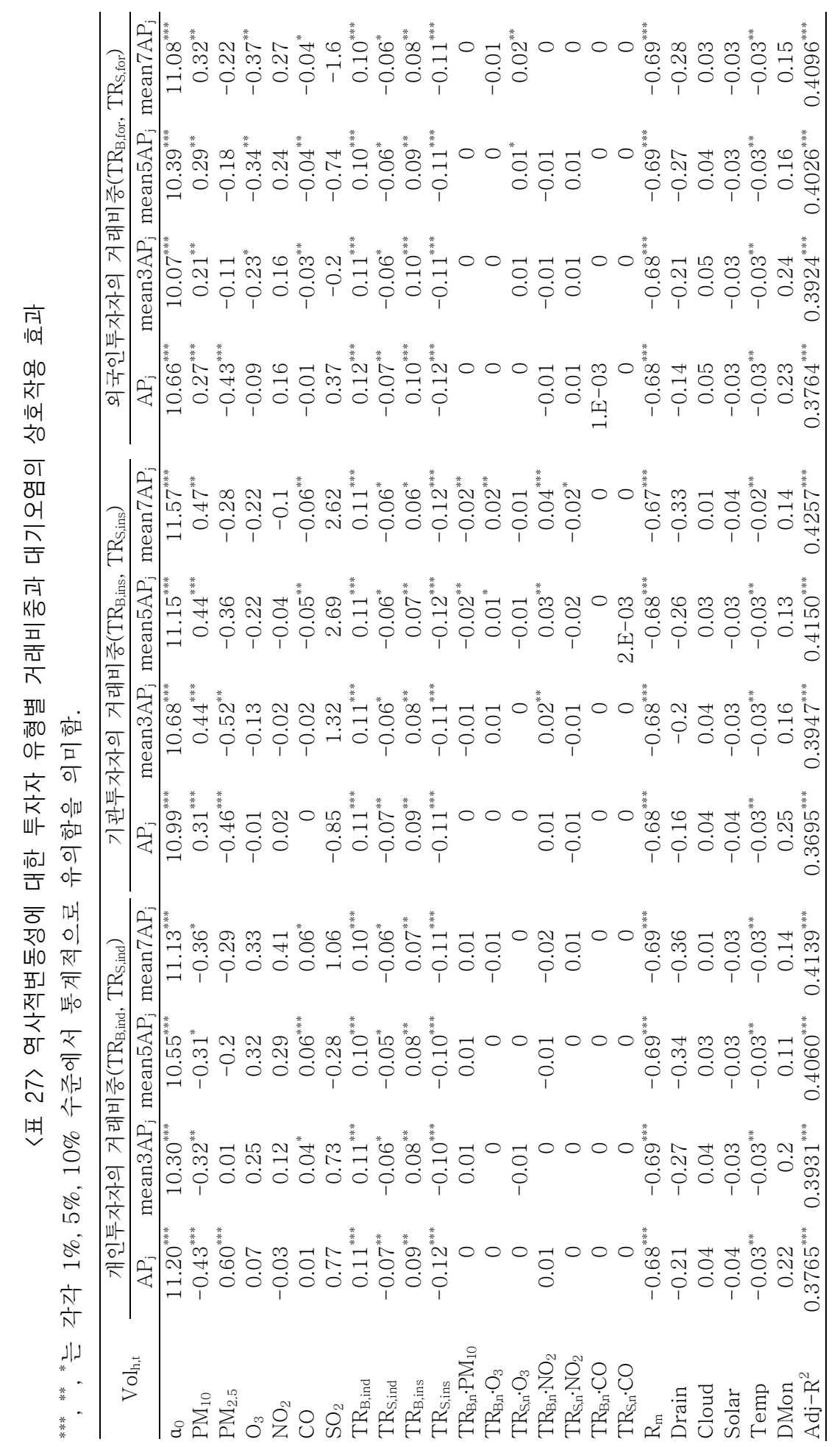




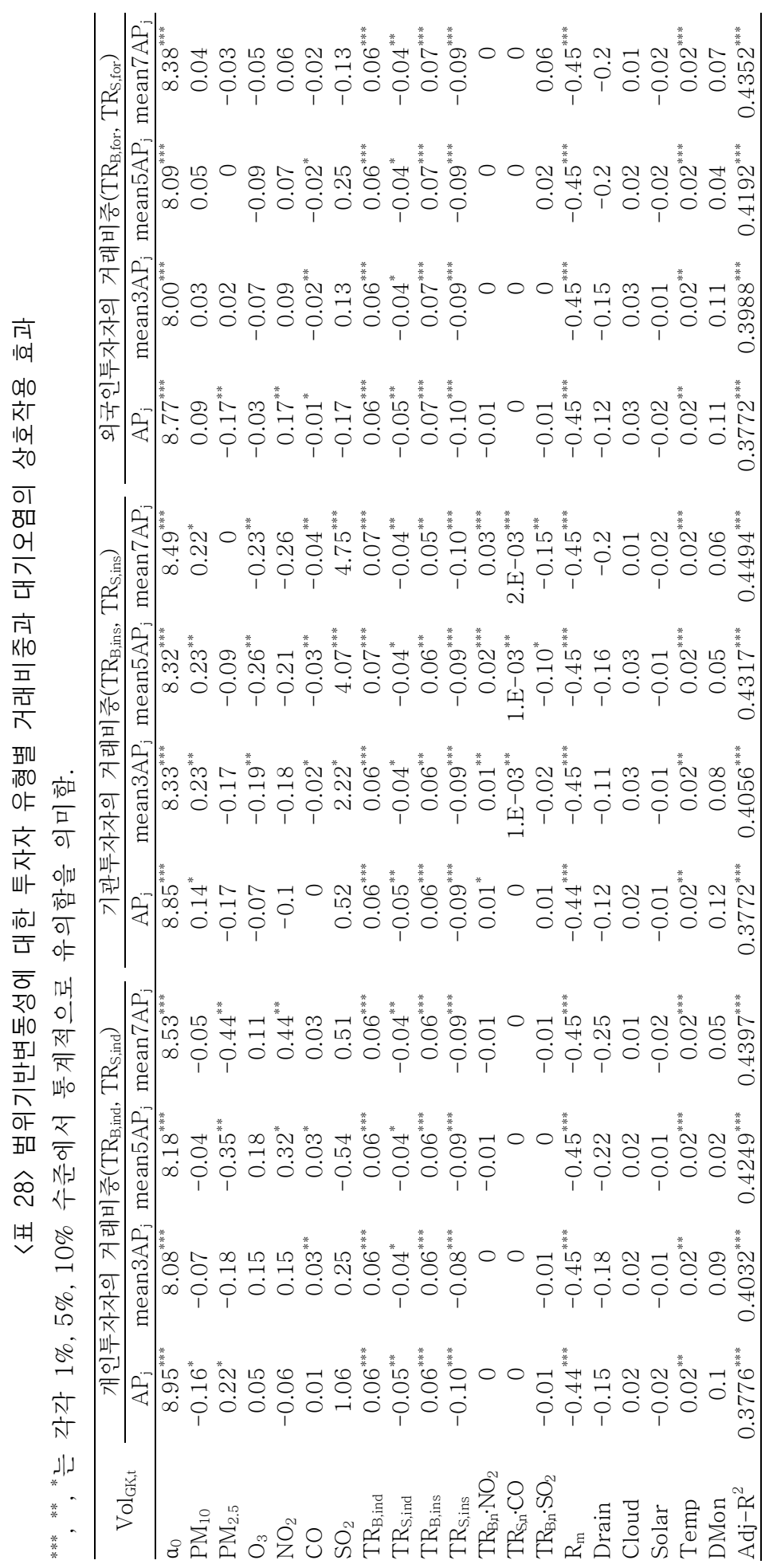


한국증권학회지 제49권 3호 (2020)

역사적변동성에 대한 회귀분석 결과, 기관의 매수비중과 미세먼지의 상호작용 $\left(\mathrm{TR}_{\mathrm{B}, \mathrm{nns}}\right.$ $\mathrm{PM}_{10}$ )과 기관의 매도비중과 이산화질소의 상호작용 $\left(\mathrm{TR}_{\mathrm{S}, \mathrm{ins}} \cdot \mathrm{NO}_{2}\right)$ 과 기관의 매도비중과 일산화탄소의 상호작용 $\left(\mathrm{TR}_{\mathrm{S}, \mathrm{nn}} \cdot \mathrm{CO}\right)$ 은 역사적변동성과 유의한 음 $(-)$ 의 상관관계를 보였고, 기관의 매수비중과 오존의 상호작용 $\left(\mathrm{TR}_{\mathrm{B}, \mathrm{ins}} \cdot \mathrm{O}_{3}\right)$ 과 기관의 매수비중과 이산화질소의 상호 작용 $\left(\mathrm{TR}_{\mathrm{B}, \mathrm{ins}} \cdot \mathrm{NO}_{2}\right)$ 은 역사적변동성과 양(+)의 상관관계를 보였다. 또한 외국인의 매도비중과 오존의 상호작용 $\left(\mathrm{TR}_{\mathrm{S}, \mathrm{for}} \cdot \mathrm{O}_{3}\right)$ 과 외국인의 상호작용과 일산화탄소의 상호작용 $\left(\mathrm{TR}_{\mathrm{B}, \mathrm{for}} \cdot \mathrm{CO}\right)$ 은 역사적변동성과 양 $(+)$ 의 상관관계를, 외국인의 매수비중과 이산화질소의 상호작용 $\left(\mathrm{TR}_{\mathrm{B}, \mathrm{for}}\right.$. $\left.\mathrm{NO}_{2}\right)$ 은 역사적변동성과 음(-)의 상관관계를 띄었다.

범위기반변동성에 대한 회귀분석 결과, 기관의 매수비중과 이산화질소의 상호작용 $\left(\mathrm{TR}_{\mathrm{B}, \mathrm{ins}}\right.$. $\left.\mathrm{NO}_{2}\right)$ 은 범위기반변동성과 양(+)의 상관관계를, 기관의 매도비중과 일산화탄소의 상호작용 $\left(\mathrm{TR}_{\mathrm{S}, \mathrm{nns}} \cdot \mathrm{CO}\right)$ 과 기관의 매수비중과 아황산가스의 상호작용 $\left(\mathrm{TR}_{\mathrm{B}, \mathrm{nns}} \cdot \mathrm{SO}_{2}\right)$ 은 범위기반변동성과 음(-)의 상관관계를 보였다. 개인투자자와 외국인투자자의 경우, 범위기반변동성에 대한 간접효과는 존재하지 않았다.

대기오염물질의 장기노출시의 간접효과를 살펴보면, 변동성의 경우에는 대기오염에 장기간 노출될수록 간접효과가 크게 발견되었으나 수익률의 경우에는 오히려 대기오염에 장기간 노출시에 간접효과가 사라짐을 확인할 수 있었다. 즉, 기관의 매도비중과 일산화탄소의 상호 작용 $\left(\mathrm{TR}_{\mathrm{S}, \mathrm{nn}} \cdot \mathrm{CO}\right)$ 은 수익률과 유의한 상관관계를 보였으나, 일산화탄소에 장기간 노출시에 간접효과가 사라졌다. 당일 노출된 대기오염물질의 농도가 지수변동성에 미치는 간접효과는 기관의 매수비중과 이산화질소의 상호작용 $\left(\mathrm{TR}_{\mathrm{B}, \mathrm{ins}} \cdot \mathrm{NO}_{2}\right)$ 이외에는 존재하지 않았으나 각 대기오염물질에 장기간 노출될수록 대기오염물질의 간접효과는 크게 나타남을 알 수 있었다.

\section{6. 결론}

본 연구는 대기오염물질로 인한 투자심리의 변화가 국내 코스피지수수익률 및 변동성에 미치는 직접적인 영향과 투자자별 거래비중을 통한 간접적인 영향에 대하여 분석하였다. 실증분석 결과 몇 가지 주요한 결과를 확인할 수 있었다.

첫째, 대기오염변수와 지수수익률 및 변동성 간의 회귀분석 결과, 대기오염물질은 지수 수익률에 유의한 영향을 미치지는 않았으나, 변동성에 직접적인 영향이 있었다. 실증분석을 통해 미세먼지와 초미세먼지가 지수변동성에 음(-)의 영향을 있음을 알 수 있었다.

둘째, 대기오염변수와 투자자별 거래비중 간의 회귀분석 결과, 초미세먼지의 농도와 기관의 매수비중과 외국인의 매도비중 간에는 음(-)의 상관관계가 나타났다. 이를 통해 대기오염 물질이 투자자 유형별 거래비중에 상이한 영향을 미친다는 점을 확인할 수 있었다.

셋째, 대기오염의 장기간노출과 지수수익률 및 변동성 간의 회귀분석 결과, 지수수익률 및 변동성에 유의한 영향을 미치는 것을 알 수 있었다. 일산화탄소의 일평균 농도는 지수 수익률에 미치는 영향력이 유의하지 않았으나, 5 일간 노출될 경우 지수수익률에 음(-)의 
영향이 있었으며 지수변동성의 경우에도 대기오염물질의 노출기간이 길수록 더 많은 영향력이 있음을 알 수 있었다. 또한 대기오염의 장기간노출과 투자자별 거래비중이 지수수익률 및 변동성에 미치는 영향에 관한 분석 결과에서도 초미세먼지와 이산화질소, 일산화탄소에 장기간 노출되면 지수수익률이 감소하고 지수변동성의 경우에도 대기오염에 장기간 노출 될수록 지수변동성의 추정치의 크기가 증가하는 결과가 나타났다. 이는 대기오염물질과 주가수익률 간에 음(-)의 상관관계가 나타난다는 기존 연구의 결과와 일치한다(Levy and Yagil, 2011; Lepori, 2009; Li and Peng, 2016). 이는 대기오염물질의 노출기간이 주식시장에 미치는 영향력에 관하여 분석한 첫 논문이며 노출 기간이 유의한 영향력을 나타냈다는 점에서 의의가 있다.

마지막으로 본 연구는 투자자 유형별 거래비중을 통한 대기오염물질의 간접효과를 고려 하였다. 그 결과, 기관의 경우에는 지수수익률과 변동성에 대한 간접효과가, 외국인의 경우에는 변동성에 대한 간접효과가 발견되었으나, 개인의 경우에는 간접효과가 발견되지 않았다. 기관투자자의 경우, 일산화탄소는 지수수익률에 간접적 영향을 미쳤고, 미세먼지, 오존, 이산화질소, 일산화탄소, 아황산가스 등 5 가지 대기오염물질은 지수변동성에 간접적 영향을 미쳤다. 그리고 외국인투자자의 경우에는 오존, 일산화탄소, 이산화질소는 변동성에 간접적 영향을 미쳤다. 각 대기오염물질에 장기간 노출될수록 기관투자자의 간접효과는 더 크게 나타났으나 외국인의 경우에는 대기오염물질의 노출기간에 따른 영향은 나타나지 않았다.

본 연구는 투자자별 거래비중을 통해 대기오염물질과 코스피지수의 수익률 및 변동성 간의 관계에 대하여 분석한 첫 연구라는 점에서 상당한 의의가 있다. 분석 결과, 대기오염이 지수수익률과 변동성에 직·간접적으로 영향을 미치며 그 영향력은 투자자별로 상이하였고 이는 효율적 시장가설의 타당성에 의문을 제기한다. 기관과 외국인투자자의 거래비중을 통해 대기오염이 간접적으로 지수수익률과 변동성에 영향을 미치는 것으로 나타났으며 실무적으로 이를 활용하여 주식거래뿐만 아니라 파생상품 거래에 도움이 될 것으로 생각 한다. 또한 대기오염이 위험요인으로 미세하게나마 작용하기 때문에 향후 대기오염 관련 상품이 헤지 수단으로 이용될 수 있으므로 규제당국에서도 인지할 필요가 있다.

특히, 현지날씨에 영향을 받지 않는다고 알려진(Kang et al., 2010) 외국인투자자의 거래 비중을 통한 대기오염의 간접적인 영향은 본 연구에서 밝혀진 주목할 만한 결과이다. 외국인 투자자는 국내 주식시장에서 개인 및 기관투자자의 거래패턴에 대해 군집행동을 하는 경향이 있으므로 이에 따라 외국인의 간접효과가 발생했다고 추론할 수 있으며, 외국인은 현지 날씨에 영향을 받지 않는다고 주장한 기존 연구 결과에 반론을 제기하며 한 걸음 나아간 결과라 볼 수 있다. 


\section{References}

Baker, M., and J. C. Stein, 2004, Market liquidity as a sentiment indicator, Journal of Financial Markets, Vol. 7 (3), pp. 271-299.

Brock, W. A., and C. H. Hommes, 1998, Heterogeneous beliefs and routes to chaos in a simple asset pricing model, Journal of Economic Dynamics and Control, Vol. 22 (8-9), pp. 1235-1274.

Brown, G. W., and M. T. Cliff, 2004, Investor sentiment and the near-term stock market, Journal of Empirical Finance, Vol. 11 (1), pp. 1-17

Choe, H., B. Kho, and R. M. Stulz, 2001, Do domestic investors have more valuable information about individual stocks than foreign investors? NBER Working Paper No. 8073, Cambridge, Ma.

Cao, M., and J. Wei, 2005, Stock market returns: A note on temperature anomaly, Journal of Banking and Finance, Vol. 29 (6), pp. 1559-1573.

Garman, M. B., and M. J. Klass, 1980, On the estimation of security price volatilities from historical data. The Journal of Business, Vol. 53 (1), pp. 67-78.

Goetzmann, W. N., and N. Zhu, 2005, Rain or shine: Where is the weather effect?, European Financial Management, Vol. 11 (5), pp. 559-578.

Isen, A. M., T. E. Shalker, M. Clark, and L. Karp, 1978, Affect, accessibility of material in memory, and behavior: A cognitive loop?, Journal of Personality and Social Psychology, Vol. 36 (1), pp. 1-12.

Jung, J., S. Chu, J. Kim, T. Han, S. Park, J. Chung, and H. Kim, 2018, Correlation of respiratory syncytial virus infection with climate parameters and air pollution levels in Korean children during 2005-2012, Allergy Asthma \& Respiratory Disease, Vol. 6 (4), pp. 206-210.

Kang, S. H., Z. Jiang, Y. Lee, and S. Yoon, 2010, Weather effects on the returns and volatility of the Shanghai stock market, Physica A: Statistical Mechanics and its Applications, Vol. 389 (1), pp. 91-99.

Khil, J., N. Y. Kim, and E. J. Lee, 2009, Investors' Trading Behavior and Asymmetric Volatility, Journal of Money \& Finance, Vol. 23 (3), p. 25.

Kim, W. C., 2001, Foreign Portfolio Investors: Are They Different?, Korea Institute of Finance, Panel for Korean Economic Analysis, Vol. 7 (2).

Kim, Y., S. Yoon, and S. Woo, 2018, Relation of allergic rhinitis, allergen sensitization, and air pollutants in preschool children, Allergy Asthma \& Respiratory Disease, Vol. 6 (2), 
Air Pollution, Stock Return, and Volatility

pp. 197-205.

Kho, B. C. and J. W. Kim, 2017, Who Drive the Rise and Fall of the Bubbles in Korean Stock Market?, Korean Journal of Futures and Options, Vol. 25 (4), pp. 591-622.

Lee, W. Y., C. X. Jiang, and D. C. Indro, 2002, Stock market volatility, excess returns, and the role of investor sentiment, Journal of Banking and Finance, Vol. 26 (12), pp. 2277-2299.

Lepori, G. M., Environmental stressors, mood, and investment decisions: Evidence from ambient air pollution, Working Paper, 2009, Retrieved from https://efmaefm.org/OEF MAMEETINGS/EFMA\%20ANNUAL\%20MEETINGS/2009-Milan/papers/EFMA2009 _0002_fullpaper.pdf.

Lepori, G. M., 2016, Air pollution and stock returns: Evidence from a natural experiment, Journal of Empirical Finance, Vol. 35, pp. 25-42.

Levy, T., and J. Yagil, 2011, Air pollution and stock returns in the US, Journal of Economic Psychology, Vol. 32 (3), pp. 374-383

Li, Q., and C. H. Peng, 2016, The stock market effect of air pollution: Evidence from china, Applied Economics, Vol. 48 (36), pp. 3442-3461.

Lim, Y. H., H. Kim, J. H. Kim, S. Bae, H. Y. Park, and Y. C. Hong, 2012, Air pollution and symptoms of depression in elderly adults, Environmental Health Perspectives, Vol. 120 (7), p. 1023.

Lu, J. G., J. J. Lee, F. Gino, and A. D. Galinsky, 2018, Polluted morality: Air pollution predicts criminal activity and unethical behavior, Psychological Science, Vol. 29 (3), pp. 340355.

Nofsinger, J. R., 2005, Social mood and financial economics, Journal of Behavioral Finance, Vol. 6 (3), pp. 144-160.

Park, B., 2016, Investors' Herd Behavior and its Relation with Volatility in the Korean Stock Market, Bank of Korea, Vol. 22 (3), pp. 70-93.

Parkinson, M., 1980, The extreme value method for estimating the variance of the rate of return, The Journal of Business, Vol. 53 (1), pp. 61-65.

Poterba, J. M., and L. H. Summers, 1988, Mean reversion in stock prices: Evidence and implications, Journal of Financial Economics, Vol. 22 (1), pp. 27-59.

Ryu, D., H. Kim, and H. Yang, 2017, Investor sentiment, trading behavior and stock returns, Applied Economics Letters, Vol. 24 (12), pp. 826-830.

Saunders, E. M., 1993, Stock prices and wall street weather, The American Economic Review, Vol. 83 (5), pp. 1337-1345. 
한국증권학회지 제49권 3호 (2020)

Schwarz, J., 2000, The distributed lag between air pollution and daily deaths, Epidemiology, Vol. 11 (3), pp. 320-326.

Shim, H., H. Kim, J. Kim, and D. Ryu, 2015, Weather and stock market volatility: the case of a leading emerging market, Applied Economics Letters, Vol. 22 (12), pp. 987-992.

Wright, W. F., and G. H. Bower, 1992, Mood effects on subjective probability assessment, Organizational Behavior and Human Decision Processes, Vol. 52 (2), pp. 276-291.

Wu, Q., Y. Hao, and J. Lu, 2018, Air pollution, stock returns, and trading activities in china, Pacific-Basin Finance Journal, Vol. 51, pp. 342-365.

Yoo, S. Y., 2014, Volatility and Trading Volumes of Trader Types in KOSPI200 Index, Futures, and Options Markets, Korean Journal of Futures and Options, Vol. 22 (1), pp. 91-115.

Yun, C. H., and S. G. Lee, 2003, The Impact of Trading Volumes by Trader Types in the KOSPI200 Futures Market, Korean Journal of Futures and Options, Vol. 11 (2), pp. 126.

Yun, K., 1994, A Study on the Investment Behavior of Investor Groups, Korean Securities Assocoation, Vol. 16 (1), pp. 151-189.

Zhang, Y., Y. Jiang, and Y. Guo, 2017, The effects of haze pollution on stock performances: Evidence from china, Applied Economics, Vol. 49 (23), pp. 2226-2237. 